\title{
Review of Porphyrin Derivatives and Application in Photodynamic Therapy
}

\author{
Sarah Raquel De Annunzio, Natalia Caroline Silva Costa
}

School of Pharmaceutical Sciences, São Paulo State University

Abstract: Recent scientific research has shown the use of chlorin, phthalocyanines, and porphyrins derivatives as photosensitizers in photodynamic therapy in the treatment of various pathologies, including some of the major skin diseases. Thus, the main goal of this critical review is to catalog the papers that used these photosensitizers in the treatment of acne vulgaris, psoriasis, papillomavirus infections, cutaneous leishmaniasis, and skin rejuvenation, and to explore the photodynamic therapy mechanisms against these conditions alongside their clinical benefits.

Keywords: photodynamic therapy; chlorins; phthalocyanines; porphyrins; skin diseases; skin rejuvenation

\section{Introduction}

Although the benefits of sun exposure in promoting health and the application of light as a therapy for the treatment of cutaneous disorders in combination (or not) with photosensitive molecules are well-known since the early civilizations of China, Greece, and Egypt [1], the first scientific research using photodynamic therapy (PDT) was performed only in 1900 by Oscar Raab, when he observed the photosensitive activity of acridine orange dye in Paramecium caudatum, when subjected to irradiation in the presence of oxygen, leading Paramecium caudatum to death [2]. In 1903 Hermann Von Tappeiner observed that the combination of eosin and light caused a reduction in skin diseases, such as condylomata, psoriasis, skin cancer, lupus vulgaris, and syphilis. It is now well established in the literature that the action of PDT depends on the absorption of visible light by a suitable photosensitive agent that will produce reactive oxygen species (ROS), which can destroy microorganisms, blood vessels, and cancer cells [3]; its application in the treatment of skin diseases has gained prominence and interest around the world. Although most skin disorders alone do not pose any threat to the life of patients, the growing demand for improvements in skin appearance, mostly associated with the patient's selfesteem and quality of life is undeniable. Therefore, the continuous introduction of new light sources and photosensitizers (PS) associated with the easy access of the skin to photonic therapies contribute to the growing use of PDT for the treatment of various cutaneous conditions [4].

Topical application of PDT is an innovative therapeutic option and corresponds to the evolution of inflammatory disease treatment including acne vulgaris and psoriasis, or infectious diseases such as cutaneous leishmaniasis and verruca vulgaris. Moreover, the application of this therapy in skin rejuvenation has been widely studied $[5,6]$.

The compounds chlorin, porphyrin, and phthalocyanine have been commonly used as PS, mainly due to their photophysical characteristics suitable for PDT application such as high quantum yield of singlet oxygen and the light absorption at $600-750 \mathrm{~nm}$, contributing to the applications that require greater light penetration [7,8]. Additionally, there are some PS belonging to this group of molecules that are already in the market and are approved for clinical use [9-11] (Table 1).

Table 1. Photosensitizers approved for clinical use. In this review, we summarize the investigations of the last 15 years using chlorin, phthalocyanine, and porphyrin derivatives as PS in the treatment of acne vulgaris, psoriasis, papilloma virus infections, cutaneous leishmaniasis, and skin rejuvenation, and discuss the mechanisms of PDT against these conditions and observe their clinical actions.

\begin{tabular}{|c|c|c|}
\hline PS Type & Product & Application \\
\hline \multirow{2}{*}{ Chlorin } & Foscan ${ }^{\circledR}$ & Approved in Europe for head and neck cancer \\
\hline & Laserphyrin ${ }^{\circledR}$ & Approved in Japan lung cancer \\
\hline \multirow{3}{*}{ Porphyrin } & Photofrin ${ }^{\circledR}$ & $\begin{array}{l}\text { Approved in the United States for esophageal cancer; Approved in Japan for } \\
\text { gastric cancer; Approved in Canada for recurrent bladder cancer }\end{array}$ \\
\hline & Metvix ${ }^{\circledR}$ & Approved in the United States and Europe for actinic keratosis \\
\hline & Levulan ${ }^{\circledR}$ & Approved in the United States and Europe for actinic keratosis \\
\hline
\end{tabular}




\begin{tabular}{|c|c|c|}
\hline & Photogem ${ }^{\circledR}$ & Approved in Russia for basal cell carcinoma \\
\hline & Visudyne ${ }^{\circledR}$ & Approved in China and the United States for macular degeneration \\
\hline Phthalocyanine & Photosens ${ }^{\circledR}$ & $\begin{array}{c}\text { Approved in Russia and India for sarcoma and choroidal, eye, eyelid, cervical, } \\
\text { bladder tumors }\end{array}$ \\
\hline
\end{tabular}

\section{Photodynamic Therapy and Photosensitizers}

Briefly, a low-intensity visible light source, a non-toxic dye in the absence of light, i.e., a PS, and the presence of oxygen in the target cell or tissue are necessary for PDT. PS is excited by light in a specific wavelength, giving rise to two reactions (type I and the type II) that can occur simultaneously. In type I reactions, the excited triplet state can react with the biomolecules by transferring charges, resulting in radicals and radical ions that react with molecular oxygen, causing the production of ROS. In type II reaction, the direct energy transfer occurs from the PS in the triplet excited state to the oxygen in the fundamental triplet state, forming singlet oxygen, a highly cytotoxic form [12-14].

Recently, Scherer et al., 2017 [15] described the types III and IV mechanisms of photodynamic reactions that are not dependent on the presence of oxygen, allowing the occurrence of cytotoxic effects in intracellular structures. Type III photosensitive molecules are usually antioxidant carrier sensitizers (ACS), presenting properties that increase the generation of singlet oxygen and decrease the concentration of native free radicals in the target cells. For type IV, the authors suggest that their cytotoxic mechanism is related to the PS that are not able to bind to a molecular target, but under light excitation, an intramolecular remodeling occurs through a photoisomeration process, contributing to the binding of photosensitive molecule to its molecular target.

In order to be used in PDT, the PS must meet some criteria, such as low (or no) toxicity in the absence of light, high selectivity, non-prolonged photosensitivity, chemical purity, and low aggregation in solutions [16,17].

The following sections present the literature reports showing the use of PSs of the type chlorins, phthalocyanines, and porphyrins in the treatment of acne vulgaris, psoriasis, cutaneous leishmaniasis, and skin rejuvenation.

\section{Acne Vulgaris}

Acne vulgaris is a chronic inflammatory skin disease characterized by the excessive growth of the microorganism Cutibacterium acnes, formerly known as Propionibacterium acnes, in the sebaceous glands [18].

According to the Global Burden of Disease, acne affects approximately 50 million people in the United States annually and 600 million people around the world, ranking this skin disease as the eighth most prevalent disease in the world in 2012 [19-21]. Although acne is not a life threatening disease, different studies have reported the severe psychological effects in patients, which can affect sociability, cause phobias, and lead to depression symptoms [22-24].

Conventional acne treatments consist of the topical application of retinoids/benzoyl peroxide or antibiotics such as tetracyclines and isotretinoin, which can also be systemically administered [25-27]. However, these therapies can cause skin irritation and lead to poor patient compliance, as they require daily use [28]. Another important aspect refers to the prolonged use of antibiotics, which can be ineffective [29], contribute to the development of resistant microorganisms, and present several side effects requiring rigorous monitoring [30]. Therefore, the search for new, safe, and efficient therapeutic measures is necessary. In this context, PDT has been suggested as an alternative for treatment of acne. Several studies have shown that PDT is safe and effective for inflammatory and non-inflammatory acne lesions and can significantly improve these lesions [5,31]. Moreover, because ROS produced by PDT does not present any specific molecular target, it is easy to bypass microbial drug resistance, conferring advantage to this therapy over antibiotic treatments [32]. The efficiency of PDT against acne vulgaris are mainly due to the reduction of sebum produced by the sebaceous glands, reduction of $C$. acnes load, occlusion of the pilosebaceous orifice causing keratinocytes detachment, and reduction of scar formation [33-35].

In the past years, several in vitro and clinical studies have been developed mainly using 5-aminolevulinic acid (ALA) and methyl aminolevulinate (MAL) as PS in PDT in the treatment of acne [36,37]. However, recently, in vitro and in vivo studies using chlorins have also presented satisfactory results [38]. On the other hand, phthalocyanines, to our knowledge, have not been investigated to date for the treatment of this dermatosis. Table 2 shows the detailed studies using chlorins and porphyrins as PSs against acne vulgaris [37-58]. 
Table 2. Descriptions of the studies that used derivatives of porphyrins and chlorins for the treatment of acne vulgaris.

\begin{tabular}{|c|c|c|c|c|c|c|c|c|}
\hline $\begin{array}{l}\text { First Author } \\
\text { and Year }\end{array}$ & $\begin{array}{l}\text { Type of } \\
\text { Study }\end{array}$ & PS & $\begin{array}{l}\text { Chemical } \\
\text { Family }\end{array}$ & $\begin{array}{l}\text { Concentration } \\
\text { (PS) }\end{array}$ & $\begin{array}{l}\text { Pre-Irradiation } \\
\text { Time }\end{array}$ & Light Source & Dose of Light & Results \\
\hline $\begin{array}{l}\text { Pollock et al., } \\
2004\end{array}$ & Clinical & ALA & Porphyrin & $20 \%$ & $3 \mathrm{~h}$ & Laser $635 \mathrm{~nm}$ & $15 \mathrm{~J} / \mathrm{cm}^{2}$ & $\begin{array}{l}\text { A statistically significant reduction in the count of inflammatory acne } \\
\text { lesions was obviated after second application of ALA-PDT. }\end{array}$ \\
\hline $\begin{array}{l}\text { Hörfelt et al., } \\
\quad 2006\end{array}$ & Clinical & MAL & Porphyrin & $160 \mathrm{mg} / \mathrm{g}$ & $3 \mathrm{~h}$ & Red light $635 \mathrm{~nm}$ & $37 \mathrm{~J} / \mathrm{cm}^{2}$ & $\begin{array}{l}\text { Although MAL-PDT was effective in treating moderate to severe } \\
\text { opposing facial acne, further studies are still needed. }\end{array}$ \\
\hline $\begin{array}{l}\text { Hörfelt et al., } \\
\quad 2007\end{array}$ & Clinical & ALA & Porphyrin & $20 \%$ & $3 \mathrm{~h}$ & Red light $635 \mathrm{~nm}$ & $30,50,70 \mathrm{~J} / \mathrm{cm}^{2}$ & $\begin{array}{l}\text { Of } 15 \text { patients, } 8 \text { presented clinical improvement after PDT. No } \\
\text { significant reduction of } P \text {. acnes or sebum excretion after PDT was } \\
\text { observed. Thus, the authors suggest that other mechanisms of action of } \\
\text { PDT in acne may be involved that are not correlated to the eradication of } P \text {. } \\
\text { acnes and decrease in sebum secreted by the sebaceous glands. }\end{array}$ \\
\hline $\begin{array}{l}\text { Hörfelt et al., } \\
\quad 2009\end{array}$ & Clinical & MAL & Porphyrin & $160 \mathrm{mg} / \mathrm{g}$ & $3 \mathrm{~h}$ & Red light $635 \mathrm{~nm}$ & $15 \mathrm{~J} / \mathrm{cm}^{2}$ & $\begin{array}{l}\text { Although PDT and phototherapy significantly decreased acne score, no } \\
\text { significant difference was observed between the PDT group and the group } \\
\text { that solely applied light. Fluorescence maps showed low } \\
\text { selectivity for MAL-induced fluorescence in acneic lesions suggesting a } \\
\text { mechanism of total and non-selective photoablation. No significant } \\
\text { reduction of } P \text {. acnes and sebum excretion was found. }\end{array}$ \\
\hline $\begin{array}{l}\text { Bissonnette et al., } \\
2010\end{array}$ & Clinical & MAL & Porphyrin & $80 \mathrm{mg} / \mathrm{g}$ & $90 \mathrm{~min}$ & Red light & 25 or $27 \mathrm{~J} / \mathrm{cm}^{2}$ & $\begin{array}{l}\text { MAL-PDT without occlusion reduced the number of inflammatory } \\
\text { lesions in patients with facial acne vulgaris. }\end{array}$ \\
\hline $\begin{array}{l}\text { Mal et al., } \\
2013\end{array}$ & Clinical & ALA & Porphyrin & $5 \%$ & $1 \mathrm{~h}$ & LED $633 \mathrm{~nm}$ & $96-120 \mathrm{~J} / \mathrm{cm}^{2}$ & $\begin{array}{l}\text { The parameters of PDT used in this study were ideal for treating } \\
\text { different degrees of acne in Chinese patients, presenting higher activity for } \\
\text { grade IV cystic acne and mild side effects. }\end{array}$ \\
\hline $\begin{array}{l}\text { Mei, Shi, and } \\
\text { Piao } 2013\end{array}$ & Clinical & ALA & Porphyrin & $10 \%$ & $1 \mathrm{~h}$ & $\begin{array}{l}\text { Intense pulsed light } \\
420-950 \mathrm{~nm}\end{array}$ & $10-13 \mathrm{~J} / \mathrm{cm}^{2}$ & $\begin{array}{l}\text { ALA-IPL-PDT was effective in the treatment of moderate to severe acne } \\
\text { vulgaris, presenting mild to transient side effects. }\end{array}$ \\
\hline $\begin{array}{l}\text { Pinto et al., } \\
\quad 2013\end{array}$ & Clinical & MAL & Porphyrin & $160 \mathrm{mg} / \mathrm{g}$ & $90 \mathrm{~min}$ & Red light $635 \mathrm{~nm}$ & $37 \mathrm{~J} / \mathrm{cm}^{2}$ & $\begin{array}{l}\text { PDT presented faster action and better response than the red light alone and } \\
\text { could reduce sebaceous gland size and cause acne remission in the long } \\
\text { run. }\end{array}$ \\
\hline $\begin{array}{l}\text { Jeon et al., } \\
2015\end{array}$ & In vitro & Chlorin- e6 & Chlorin & $100 \mu \mathrm{g} / \mathrm{ml}$ & Uninformed & Halogen light & Uninformed & PDT was effective against inflammation caused by $P$. acnes. \\
\hline Pariser, 2016 & Clinical & MAL & Porphyrin & $80 \mathrm{mg} / \mathrm{g}$ & $1.5 \mathrm{~h}$ & LED $635 \mathrm{~nm}$ & $37 \mathrm{~J} / \mathrm{cm}^{2}$ & $\begin{array}{l}\text { MAL }(80 \mathrm{mg} / \mathrm{g}) \text {-PDT may be promising for the treatment of severe acne } \\
\text { vulgaris. }\end{array}$ \\
\hline Ma et al., 2015 & Clinical & ALA & Porphyrin & $5 \%$ & $1 \mathrm{~h}$ & LED $633 \mathrm{~nm}$ & $90-96 \mathrm{~J} / \mathrm{cm}^{2}$ & $\begin{array}{l}\text { The therapy was effective for acne vulgaris in adolescents and the } \\
\text { adverse effects were moderate and reversible. }\end{array}$ \\
\hline Tao et al., 2015 & Clinical & ALA & Porphyrin & $3.6 \%$ & $1.5 \mathrm{~h}$ & LED $633 \mathrm{~nm}$ & $126 \mathrm{~J} / \mathrm{cm}^{2}$ & $\begin{array}{l}\text { PDT was effective for the treatment of moderate to severe acne in } \\
\text { Chinese patients and showed mild and transient adverse effects. }\end{array}$ \\
\hline Tao et al., 2016 & Clinical & ALA & Porphyrin & $3.6 \%$ & $1.5 \mathrm{~h}$ & LED $633 \mathrm{~nm}$ & $126 \mathrm{~J} / \mathrm{cm}^{2}$ & ALA-PDT was efficient and safe for the treatment of severe acne vulgaris. \\
\hline $\begin{array}{l}\text { Yew et al., } \\
2016\end{array}$ & Clinical & ALA & Porphyrin & $5 \%$ & $3 \mathrm{~h}$ & Red light $630 \mathrm{~nm}$ & $37 \mathrm{~J} / \mathrm{cm}^{2}$ & PDT was efficient and showed few adverse effect. \\
\hline
\end{tabular}




\begin{tabular}{|c|c|c|c|c|c|c|c|c|}
\hline Ma et al., 2016 & $\begin{array}{l}\text { Ex vivo and in } \\
\text { vitro }\end{array}$ & ALA & Porphyrin & $5 \%$ & $2 \mathrm{~h}$ & LED 633nm & $96-108 \mathrm{~J} / \mathrm{cm}^{2}$ & $\begin{array}{l}\text { PDT inhibited the innate immune response in } P . \text { acnes-infected } \\
\text { keratinocytes via TLRs pathway }\end{array}$ \\
\hline \multicolumn{9}{|c|}{ Table 2. Cont. } \\
\hline $\begin{array}{l}\text { First Author } \\
\text { and Year }\end{array}$ & $\begin{array}{l}\text { Type of } \\
\text { Study }\end{array}$ & PS & $\begin{array}{l}\text { Chemical } \\
\text { Family }\end{array}$ & $\begin{array}{l}\text { Concentration } \\
\text { (PS) }\end{array}$ & $\begin{array}{l}\text { Pre-Irradiation } \\
\text { Time }\end{array}$ & Light Source & Dose of Light & Results \\
\hline $\begin{array}{l}\text { Ryu and Lee } \\
2017\end{array}$ & In vitro & Chlorin -e6 & Chlorin & $\begin{array}{l}0.05,0.1,0.15 \\
0.2 \mu \mathrm{M}\end{array}$ & $30 \mathrm{~min}$ & Halogen light & uninformed & $\begin{array}{l}\text { Was observed an increase in collagen production by chlorin-mediated } \\
\text { PDT, suggesting its potential use for scar amelioration and skin } \\
\text { rejuvenation in acne treatment. }\end{array}$ \\
\hline $\begin{array}{c}\text { Kim et al., } \\
2017\end{array}$ & $\begin{array}{l}\text { Randomized } \\
\text { and } \\
\text { comparative }\end{array}$ & MAL & Porphyrin & $160 \mathrm{mg} / \mathrm{g}$ & $30 \mathrm{~min}$ & $\begin{array}{l}\text { Ablative } 1550 \mathrm{~nm} \\
\text { fractional erbium glass } \\
\text { laser }\end{array}$ & $20 \mathrm{~mJ} / \mathrm{cm}^{2}$ & $\begin{array}{l}\text { Daylight-PDT associated with MAL showed clinically good responses to } \\
\text { inflammatory lesions in patients with moderate to severe acne. }\end{array}$ \\
\hline $\begin{array}{l}\text { Wang et al., } \\
2017\end{array}$ & $\begin{array}{l}\text { In vitro and in } \\
\text { vivo }\end{array}$ & Chlorin-e6 & Chlorin & $0.1,0.5 \mathrm{e} 1 \mu \mathrm{M}$ & $30 \mathrm{~min}$ & Halogen light & uninformed & $\begin{array}{l}\text { Chlorin-e6-PDT suppressed } P . \text { acnes-induced inflammation through } \\
\text { modulation of NFKB and MAPKs signaling pathways. }\end{array}$ \\
\hline $\begin{array}{l}\text { Wang et al., } \\
2017\end{array}$ & In vivo & ALA & Porphyrin & $50 \%$ & $2 \mathrm{~h}$ & $\begin{array}{l}\text { Red light } \\
630 \mathrm{~nm} \text { (optical } \\
\text { Intra-tissue fiber } \\
\text { irradiation) }\end{array}$ & $4.5 \mathrm{~J} / \mathrm{cm}^{2}$ & $\begin{array}{l}\text { The intra-tissue irradiation presented few adverse effects than the } \\
\text { conventional irradiated group, ALA. The treatment of acne in the ears of } \\
\text { rabbits using intra-tissue irradiation showed better results on day 14, but not } \\
\text { on days } 30 \text { and } 45 \text {. }\end{array}$ \\
\hline $\begin{array}{l}\text { Qureshi and Lin } \\
2017\end{array}$ & Clinical & ALA & Porphyrin & $20 \%$ & $1-3 \mathrm{~h}$ & Red laser & $50-100 \mathrm{~J} / \mathrm{cm}^{2}$ & $\begin{array}{l}\text { The combination of non-ablative fractionated laser and PDT could be used } \\
\text { in the treatment of acne, causing minimal side effects and requires fewer } \\
\text { sessions than PDT alone, probably due to the increased ALA distribution } \\
\text { caused by the pretreatment of the skin with the non-ablative fractionated } \\
\text { photothermolysis. }\end{array}$ \\
\hline Li et al., 2018 & Case report & ALA & Porphyrin & $3 \%$ & $3 \mathrm{~h}$ & LED $633 \mathrm{~nm}$ & $50 \mathrm{~J} / \mathrm{cm}^{2}$ & $\begin{array}{l}\text { This method was effective after two years of treatment, and the presence of } \\
\text { papules, without cysts and nodules, was reported. }\end{array}$ \\
\hline $\begin{array}{l}\text { De Annunzio et } \\
\text { al., } 2018\end{array}$ & In vitro & Chlorin-e6 & Chlorin & $\begin{array}{l}2.62,5.25,10.5 \\
21,42 \mu \mathrm{M}\end{array}$ & $10 \mathrm{~min}$ & LED $660 \mathrm{~nm}$ & $\begin{array}{l}3.25,7.5 \text { and } \\
15 \mathrm{~J} / \mathrm{cm}^{2}\end{array}$ & $\begin{array}{l}\text { PDT was able to reduce the total microbial load in planktonic phase of } \\
\qquad \text { P. acnes. }\end{array}$ \\
\hline
\end{tabular}




\section{Psoriasis}

Psoriasis is a skin condition that affects approximately $2.5 \%$ of the Caucasians, $1.3 \%$ of the African-American population, and $0.6 \%$ to $4.8 \%$ of the population worldwide [59]. Psoriasis has been traditionally considered as a common chronic inflammatory skin disease, which presents a broad spectrum of clinical phenotypes, triggered by an interplay of numerous factors such as environmental, immunological, and possibly genetic features, which can also be considered as participants in the development of this multifactorial disease [60]. The pathogenesis of the disease includes mainly the activation and migration of $\mathrm{T}$ cells to the dermis, triggering the release of TNF- $\alpha$, IL-6, IL-1 $\beta$, and IL-17, among other citokines, leading to an inflammatory response and increased proliferation of skin cells [61-64]. The disease treatment mainly relies on the therapeutic agents that modulate the immune system or normalize the keratinocyte differentiation program. The current available treatment are agents for topical use such as emollients, dithranol, tar, deltanoides, corticosteroids, tacrolimus, and ultraviolet radiation (UV) or for systemic use, including methotrexate, cyclosporine, acitrecine, hydroxyurea, fumarates, etc. [59]. Although its clinical efficacy, the use of combined therapy using psoralen and UVA (PUVA) [65] showed severe side effects such as nausea, headache, erythema, burns, bringing pain, and discomfort to the patient during the treatment, and consequently causing patient low compliance; besides, there is an increased risk of skin cancer development due to UVA irradiation [66]. Thus, the development of more specific, less toxic, and more bearable new therapeutic approaches is mandatory.

It was reported that the use of ALA [67-70], a substrate for the biosynthesis of the photoactive protoporphyrin IX (PPIX), on PDT for the treatment of psoriasis causes apoptosis of the T-cells [67] and a decrease in the production of the main citokines related to the disease development [67]. Another study showed that patients undergoing ALA treatment followed by PDT had diminished lesions and inflammatory response [66]. The reduction in cell proliferation can be related to the activation of the MAPK pathway, promoting an increased level of expression of the apoptosis related genes $p 38$, JNK and ERK, PARP and caspase 3 [66]. Other studies have been conducted in order to identify new synthetic PS porphyrins to be applied on the treatment of this skin disorder [71,72].

The metallophthalocyanine ZnPc-F7, a phthalocyanine agent $\alpha$-(8-quinolinoxy) zinc, is a metal coordinated compound presenting good solubility, low toxicity, and a strong effect on disease control. This metal-based compound is excited at $670 \mathrm{~nm}$, allowing it to reach deeper layers of skin, besides its safeness when compared to PUVA-based treatment. The antipsoriasis effect of $\mathrm{ZnPc-F7}$ reduced both HaCaT cell proliferation after light irradiation at $670 \mathrm{~nm}$ as well as the levels of IL-17, diminishing the psoriatic lesions $[59,66]$.

Another PS that was active against skin inflammation is the silicon phthalocyanine (Pc) 4 coupled with red light. It has been shown that (Pc) 4 cause cell death when evaluated against cell lines derived from lymphoids (Jurkat) or epithelium (A431), highlighting singlet oxygen and ROS generation as possible inducers of cell death, acting in a dose-response way, i.e., the higher the concentration of the compound the greater the number of apoptotic cells [73]. The studies of phthalocyanines and porphyrins on PDT applied in the treatment of skin disorder are available in Table 3 [66,71,73-75]. 
Table 3. Descriptions of studies using porphyrins and phthalocyanines in the treatment of psoriasis.

\begin{tabular}{|c|c|c|c|c|c|c|c|c|}
\hline First Author and Year & $\begin{array}{l}\text { Type of } \\
\text { Study }\end{array}$ & PS & Chemical Family & Concentration (PS) & $\begin{array}{l}\text { Pre-Irradiation } \\
\text { Time }\end{array}$ & Light Source & Dose of Light & Results \\
\hline Fransson e Ros, 2005 & Clinical & ALA & Porphyrin & $\begin{array}{l}\text { Freshly made cellulose gel } \\
\text { (sodium } \\
\text { carboxymethylcellulose in } \\
\text { sterile water) } \\
\text { containing } 20 \% \delta \text {-ALA } \\
\text { hydrochloride }\end{array}$ & $\begin{array}{l}\text { Once weekly of two } \\
\text { to five aplications. }\end{array}$ & $\begin{array}{c}\text { Red light } \\
(\text { maximum } 630 \mathrm{~nm}) \text { ) }\end{array}$ & $10-30 \mathrm{~J} / \mathrm{cm}^{2}$ & $\begin{array}{l}\text { ALA treatment decreased the } \\
\text { number of lesions. }\end{array}$ \\
\hline Carrenho et al., 2015 & in vivo & $\begin{array}{l}\text { 5,10-diphenyl- } \\
15,20 \mathrm{di}(N- \\
\text { methylpyridinium4- } \\
\text { yl)porphyrin (Di-cis-Py+). }\end{array}$ & Porphyrin & Di-cis-Py+ (0.1 mg/ear) & $20 \mathrm{~min}$ & $\begin{array}{l}\text { Under white light from a } \\
\text { compatible } \\
\text { fiber optic probe } \\
(400-800 \mathrm{~nm})\end{array}$ & $120 \mathrm{~J} / \mathrm{cm}^{2}$ & $\begin{array}{c}\text { PDT reduced epidermis } \\
\text { hyperproliferation, edema, } \\
\text { proinflammatory cytokines, and } \\
\text { cellular infiltration. }\end{array}$ \\
\hline Jin et al., 2015 & in vivo & $\begin{array}{l}\text { Zinc phthalocyanine } \\
\text { polymer conjugate } \\
\text { (ZPB) with the } \\
\text { polyethylene glycol } \\
\text { (PEG) chain }\end{array}$ & Phthalocyanine & $\begin{array}{l}0.1 \mathrm{mg} / \mathrm{mL} \text { and } 1 \\
\mathrm{mg} / \mathrm{mL}\end{array}$ & 6 days & $\begin{array}{l}\text { UV-vis absorption } \\
\text { wavelengths, } 348 \mathrm{~nm} \text { and } \\
678 \mathrm{~nm}\end{array}$ & uninformed & $\begin{array}{l}\text { PDT showed good anti-psoriasis } \\
\text { activity, based on the light excitation of } \\
\text { the photosensitizer ZPB }\end{array}$ \\
\hline Soler et al., 2016 & in vitro & $\begin{array}{l}\text { Silicon phthalocyanine } \\
(\mathrm{Pc}) 4\end{array}$ & Phthalocyanine & $\begin{array}{l}50,100,150 \text {, and } \\
300 \mathrm{nM} \text {. }\end{array}$ & $2 \mathrm{~h}$ & Red light $(675 \mathrm{~nm})$ & $200 \mathrm{~J} / \mathrm{cm}^{2}$ & $\begin{array}{l}\text { The mechanism of action is related to } \\
\text { the generation of singlet oxygen and } \\
\text { reactive oxygen species, leading to } \\
\text { cell death through apoptosis } \\
\text { mechanism in a dose response } \\
\text { manner. }\end{array}$ \\
\hline Liu et al., 2017 & in vitro & $\begin{array}{c}\alpha \text {-(8-quinolinoxy) zinc } \\
\text { (ZnPc-F7) }\end{array}$ & Phthalocyanine & $0,10,0,30$ e $1,00 \mu \mathrm{g} / \mathrm{mL}$ & 2 days & Laser 630 e $670 \mathrm{~nm}$ & $14.15 \mathrm{~J} / \mathrm{cm}^{2}$ & $\begin{array}{l}\text { The phthalocyanine derivative } \alpha \text { - } \\
\text { (8-quinolinoxy) zinc (ZnPc-F7), } \\
\text { excited at } 670 \mathrm{~nm} \text {, reaches safely the } \\
\text { deeper layers of the skin. }\end{array}$ \\
\hline
\end{tabular}




\section{Viral Warts Caused by Human Papillomavirus (HPV)}

Warts are benign cutaneous lesions usually caused by human papillomavirus (HPV) infection [76]. According to the type and site, these viruses present varied clinical manifestations. Multiple flat warts occur on the face, which appear as flattened papules, commonly related to the HPV type 1 and 3 . These warts negatively influence the aesthetics and sociability of patients [77].

Theconventionalmodalitiesappliedforthetreatmentofthesewartsarecryotherapy, electrosurgery, topical keratolytic agents, and antimiotics. Because the application is simple and safe and present rapid response, cryotherapy has been one of the most commonly used treatment modalities. However, relapse of warts after several sections of cryotherapy is very common and, alongside this treatment, hyperpigmentation and scars formation onto the local application is frequent [78]. Thus, the search for alternative modalities is extremely important.

Clinical studies have reported that ALA has shown positive results in the treatment of recalcitrant facial warts $[79,80]$. The literature suggests that ALA is absorbed and converted to PPIX by HPV-infected keratinocytes. The early stages of viral infection can be inhibited via PPIX-mediated PDT associated with 630 $\mathrm{nm}$ laser irradiation. This combination causes the host cells to form ROS by selectively inactivating nonenveloped viral particles [80].

Additionally, a study conducted by Morton et al. [81] suggests that the mechanism of action of ALAPDTinwartsisrelatedtotheselectivephotothermolysisofoxyhemoglobininthemicrovasculature, causing damage in the dilated superficial capillaries present in these warts.

Table 4, depicts the studies that have been using porphyrin derivatives for the treatment of these warts [76,82-86]. 
Table 4. The studies that used porphyrins in the treatment of HPV viral warts.

\begin{tabular}{|c|c|c|c|c|c|c|c|c|}
\hline First Author and Year & Type of Study & PS & Chemical Family & Concentration (PS) & Pre-Irradiation Time & Light Source & Dose of Light & Results \\
\hline Smucler; Jatsová, 2005 & Clinical & ALA & Porphyrin & $20 \%$ & $3 \mathrm{~h}$ & $\begin{array}{l}\text { Pulsed dye laser } \\
\text { (PDL) } 595 \mathrm{~nm} \text { and } \\
\text { LED } 635 \mathrm{~nm}\end{array}$ & 20 and $50 \mathrm{~J} / \mathrm{cm}^{2}$ & $\begin{array}{l}\text { The combination of PDT and PDL were able } \\
\text { to cure infectious warts. }\end{array}$ \\
\hline Wang et al., 2007 & Clinical & ALA & Porphyrin & $20 \%$ & $4 \mathrm{~h}$ & $\begin{array}{l}\text { Red light } 590- \\
700 \mathrm{~nm}\end{array}$ & $50 \mathrm{~J} / \mathrm{cm}^{2}$ & $\begin{array}{l}\text { Noninvasiveness, minimal adverse effects, } \\
\text { and efficient cosmetic results make PDT as a } \\
\text { promising alternative treatment for recalcitrant } \\
\text { viral warts in Asian population. }\end{array}$ \\
\hline $\begin{array}{l}\text { Fernandéz-Guarino; Harto; } \\
\text { Jaén; } 2011\end{array}$ & Clinical & MAL & Porphyrin & $160 \mathrm{mg} / \mathrm{g}$ & $3 \mathrm{~h}$ & PDL $595 \mathrm{~nm}$ & $9 \mathrm{~J} / \mathrm{cm}^{2}$ & $\begin{array}{l}\text { PDL -PDT was effective and a tolerable } \\
\text { treatment option for recalcitrant viral warts. }\end{array}$ \\
\hline Li et al., 2014 & Clinical & ALA & Porphyrin & 5,10 , and $20 \%$ & $4 \mathrm{~h}$ & Red light $633 \mathrm{~nm}$ & $113 \mathrm{~J} / \mathrm{cm}^{2}$ & $\begin{array}{l}\text { ALA }(10 \%) \text {-PDT was efficacious and safe } \\
\text { for the treatment of recalcitrant facial } \\
\text { verruca plana. }\end{array}$ \\
\hline Qian et al., 2014 & Clinical & ALA & Porphyrin & 5,10 , and $20 \%$ & 1.5 and $3 \mathrm{~h}$ & LED $630 \mathrm{~nm}$ & $126 \mathrm{~J} / \mathrm{cm}^{2}$ & $\begin{array}{l}\text { The efficacy and safety of PDT for the } \\
\text { treatment of viral wart were dependent on the } \\
\text { number of sessions and therapy doses. }\end{array}$ \\
\hline Yang et al., 2016 & Clinical & ALA & Porphyrin & $10 \%$ & $3 \mathrm{~h}$ & LED $630 \mathrm{~nm}$ & Uninformed & $\begin{array}{l}\text { Three sessions: The optimal PDT scheme for } \\
\text { the treatment of recalcitrant flat warts on the } \\
\text { face of Chinese patients. }\end{array}$ \\
\hline
\end{tabular}




\section{Cutaneous Leishmaniasis}

Leishmaniasis is a global problem, focusing on 98 developing countries especially those in Southeast Asia, East Africa, Latin America, and the Mediterranean with 12-15 million people infected and 350 million at risk of acquiring the disease [87], and is fatal if not treated properly.

The etiological agents of these diseases are trypanosomatids parasites belonging to the genus Leishmania, which are transmitted by the bite of sandflies. During the insect blood meal, promastigote forms of the parasite are inoculated into the mammalian skin [88]. The parasites are then engulfed mainly by macrophages, followed by differentiation to intracellular amastigotes, which multiply until the rupture of the infected cells $[89,90]$.

Cutaneous leishmaniasis (CL) is the most common clinical manifestation of the disease characterized by the formation of papules that gradually progress to ulcers with an indurated border. Although most cutaneous leishmaniasis ulcers spontaneously heal over a long period that lasts months, atrophic and disfiguring scars create a substantial psychological burden for years to come. Depending on the patient immune response and the parasite species, the disease can progress to diffuse cutaneous leishmaniasis and/or mucosal leishmaniasis, leaving life-long scars and serious disability and stigma [91]. An estimated 0.7 to 1.2 million cases are reported per year worldwide, especially affecting Latin America and Middle East, with a total of 40 million people living with scars [92].

The current treatment for leishmaniasis are based on few chemotherapeutic options, which present several drawbacks, such as parenteral administration, severe side effects, and low efficacy [87,93]. The pentavalent antimonials, methylglucamine antimoniate (Glucantime ${ }^{\circledR}$ ), and sodium stibogluconate (Pentostan ${ }^{\circledR}$ ) are the first choice drugs for its treatment $[88,94]$. Other drugs, such as amphotericin B, pentamidine, and miltefosine, are the second choice drugs, but they also produce side effects that can endanger the patient's life [95].

Miltefosine is the first oral drug that can be used in the treatment of leishmaniasis [96] and is reported as more effective than antimony for the treatment of CL in Bahia, Brazil [97]; however, treatment failure has been reported [98]. Thus, newer and safer therapeutical approach is mandatory.

In this scenario, PDT has been evaluated.

ALA has been investigated for the treatment of CL, commonly associated with red and blue light. ROS formed during photodynamic action causes parasite death necrosis or apoptosis-like mechanisms [99]. Data from the literature showed that porphyrins have affinity for cell membranes and in order to improve this property and increase the stability of the compounds, liposomes containing porphyrins have been used, thus promoting the internalization of the photosensitive agents and, consequently improving the efficiency of the photodynamic therapy [100].

Chlorin-e6 is another PS that has been studied and an in vitro study by Pinto et al., [101] described that PDT mediated by this PS affected Leishmania major viability; although these authors claimed that this PS is interfering in the parasite mitochondrial activity, other assays must be done in order to corroborate this hypothesis, such as $\mathrm{O}_{2}$ consumption, ATP production, and mitochondrial membrane potential evaluation, for instance. The authors further demonstrated that this PS accumulates in the cytosol, causing parasite morphological modifications. Although the authors claimed that the potential of this PDT therapy for the treatment of CL, the lack of assays involving the amastigotes cells, the forms responsible for the development of the disease, compromise this conclusion.

Another interesting approach that has been studied is the association of PDT and conventional antileishmanial drugs, and this type of strategy is also being applied for CL [102]. For instance, the phthalocyanine chlorosaluminum liposome compound (AlClPC) was developed through nanotechnology techniques for controlled drug release, improving the drug bioavailability and diminishing the drug toxicity; thus this PS was evaluated in association with miltefosine in an in vivo CL model. Although this promising therapeutic approach is able to decrease the parasite load in the site of infection and could be done without hospitalization, the authors did not investigate its toxicity to date [103].

Moreover, in order to control the disease, the principle of PDT has been explored in order to promote parasite photo-inactivation in vitro, especially in combination with porphyrins and phthalocyanines, and used them as vaccines. Indeed, Vianna and cols [104] demonstrated that photo-inactivated parasites used as vaccine may modulate the immune response of susceptible $\mathrm{BALB} / \mathrm{c}$ mice, and prophylactics protecting them against 
challenging infections [104]. Table 5 shows the details of the parameters and results used in the studies related to PDT and cutaneous leishmaniasis [102-109]. 
Table 5. Description of studies using porphyrins, phthalocyanines, and chlorins in the treatment of cutaneous leishmaniasis.

\begin{tabular}{|c|c|c|c|c|c|c|c|c|}
\hline $\begin{array}{l}\text { First Author } \\
\text { and Year }\end{array}$ & Type of Study & PS & Chemical Family & $\begin{array}{l}\text { Concentration } \\
\text { (PS) }\end{array}$ & $\begin{array}{l}\text { Pre-Irradiation } \\
\text { Time }\end{array}$ & Light Source & Dose of Light & Results \\
\hline $\begin{array}{l}\text { Kosaka et al., } \\
2007\end{array}$ & In vitro and in vivo & ALA & Porphyrin & $0.1 \mu \mathrm{m}$ & $4 \mathrm{~h}$ & Uninformed & $50 \mathrm{~J} / \mathrm{cm}^{2}$ & ALA-PDT reduced the parasite load in mice. \\
\hline $\begin{array}{l}\text { Evangelou et } \\
\text { al., } 2011\end{array}$ & $\begin{array}{l}\text { The study conducted with a } \\
69 \text {-year-old patient with a relapse } \\
\text { of long-standing cutaneous } \\
\text { leishmaniasis. }\end{array}$ & ALA & Porphyrin & $\begin{array}{l}\text { Solution of } 20 \% \\
\text { aminolevulinic } \\
\text { acid in water }\end{array}$ & $\begin{array}{l}\text { Three times at } \\
\text { weekly intervals for } \\
\text { three months. }\end{array}$ & $\begin{array}{l}\text { Red light (light } \\
\text { emitting diodes, } \\
\quad 630 \mathrm{~nm})\end{array}$ & $0.2 \mathrm{~mL} / \mathrm{cm}^{2}$ & $\begin{array}{l}\text { Interaction of the PS with the light source } \\
\text { reduced parasite load through generation of } \\
\text { reactive oxygen species. }\end{array}$ \\
\hline $\begin{array}{l}\text { Mateus et al., } \\
\quad 2014\end{array}$ & $\begin{array}{l}\text { In vitro Leishmania (Viannia) } \\
\text { panamensis or Leishmania } \\
\text { (Leishmania) infantum } \\
\text { (Leishmania chagasi) parasites. }\end{array}$ & ALA & Porphyrin & $0.0003-0.3 \mathrm{mM}$ & $48 \mathrm{~h}$ & $597-752 \mathrm{~nm}$ & $2.5 \mathrm{~J} / \mathrm{cm}^{2}$ & $\begin{array}{l}\text { PSs is sub-localized into the host mitochondria } \\
\text { and it was proposed that intracellular parasite } \\
\text { elimination might be due to the death of the } \\
\text { hosts cells. }\end{array}$ \\
\hline $\begin{array}{l}\text { Silva et al., } \\
2015\end{array}$ & $\begin{array}{l}\text { In vitro in L. amazonenses and } \\
\text { Leishmania braziliensis }\end{array}$ & $\begin{array}{l}\mathrm{PcZn}_{4} \mathrm{So}_{3} \mathrm{H}-\mathrm{Zinc} \\
\text { phthalocyanines }\end{array}$ & Phthalocyanines & $1-10 \mu \mathrm{M}$ & $\begin{array}{l}\text { For } 3 \mathrm{~h} \text { and then } \\
\text { exposed and } \\
\text { incubate with } \\
\text { Leishmania for } 24 \mathrm{~h}\end{array}$ & $\begin{array}{l}\text { LED device at } \\
660 \mathrm{~nm}\end{array}$ & $50 \mathrm{~J} / \mathrm{cm}^{2}$ & All PcZns exhibited high photoactivity at $10 \mu \mathrm{M}$. \\
\hline $\begin{array}{l}\text { Al-Qahtani et } \\
\text { al., } 2016\end{array}$ & $\begin{array}{l}\text { Assays with Leishmania tropica } \\
\text { promastigotes and axenic } \\
\text { amastigotes in vitro }\end{array}$ & Silicon(IV)phthalocyanines & Phthalocyanines & $1 \mu \mathrm{M}$ & 2 days & $\begin{array}{c}\text { Red light } \\
\text { (wavelength } \\
\sim 650 \mathrm{~nm} \text { ) }\end{array}$ & $2{\mathrm{~J} \mathrm{~cm}-{ }^{2}}^{2}$ & $\begin{array}{l}\text { Silicon (IV) -phthalocyanine derivatives } \\
\text { presented antileishmanial effect and low } \\
\text { citotoxicity to the host cells. }\end{array}$ \\
\hline $\begin{array}{l}\text { Pinto et al., } \\
\quad 2016\end{array}$ & $\begin{array}{l}\text { In vitro study in } L . \text { major and } L . \\
\text { braziliensis promastigotes. }\end{array}$ & chlorin-e6 & Chlorin & $\begin{array}{c}400 \mu \mathrm{gg} / \mathrm{mL} \text { to } 6.25 \\
\mu \mathrm{g} / \mathrm{mL}\end{array}$ & $1 \mathrm{~h}$ & $\begin{array}{l}\text { Biotable LED } \\
\text { (Biopdi, } 450 \mathrm{~nm} \text { ) }\end{array}$ & $10 \mathrm{~J} / \mathrm{cm}^{2}$ & $\begin{array}{l}\text { The authors alleged that PDT and chlorin-e6 } \\
\text { internalization are disturbing the parasite } \\
\text { mitochondrial activity; however, other assays are } \\
\text { still missing such as } \mathrm{O}_{2} \text { consumption and } \\
\text { evaluation on parasites intracellular forms. }\end{array}$ \\
\hline $\begin{array}{l}\text { Ribeiro et al., } \\
\quad 2016\end{array}$ & $\begin{array}{l}\text { Treatment of cutaneous } \\
\text { leishmaniasis caused by } \\
\text { Leishmania }(\text { L. amazonensis }) \text { in } \\
\text { C57BL/6 mice }\end{array}$ & $\begin{array}{l}\text { Liposomal } \\
\text { chloroaluminium } \\
\text { phthalocyanine } \\
\text { (AlCIPC) }\end{array}$ & Phthalocyanines & $\begin{array}{l}\text { Oral } \\
\text { Miltefosine200 } \\
\text { mg/kg/day and } \\
\text { PDT with topical } \\
\text { AlCIPC }\end{array}$ & $\begin{array}{l}20 \text { days on alternate } \\
\text { days. }\end{array}$ & $\begin{array}{l}\text { Diode laser (BWF } \\
\text { light) at } 670 \mathrm{~nm}\end{array}$ & $80 \mathrm{~mW}$ & $\begin{array}{l}\text { Combined miltefosine and PDT therapy using } \\
\text { AICIPC as PS reduced the parasite load. }\end{array}$ \\
\hline $\begin{array}{l}\text { Viana et al., } \\
\quad 2018\end{array}$ & In vitro and in vivo & ALA & Porphyrin & $0.1-10 \mu \mathrm{M}$ & $24-48 \mathrm{~h}$ & Red light & $1-2 \mathrm{~J} / \mathrm{cm}^{2}$ & $\begin{array}{l}\text { The PS amino-PC induced photo-inactivation of } \\
\text { L. amazonensis in a dose-depedent manner. }\end{array}$ \\
\hline
\end{tabular}




\section{Skin Rejuvenation}

In addition to the application against inflammatory and infectious diseases, clinical studies have shown that the application of PDT has shown improvement in signs of skin aging [5].

Aging is characterized by the appearance of wrinkles, fine lines and small capillaries, as well as increased roughness and changes in cutaneous pigmentation [110].

In PDT, ALA, MAL, and chlorin-e6 have been used in the search for cutaneous rejuvenation. Studies suggest that the mechanism of PDT action for this purpose is associated with increased collagen type 1 and skin thickness $[38,111,112]$. Table 6 shows the studies that investigated the action of PDT on skin rejuvenation [111119]. 
Table 6. Description of the studies using porphyrin derivatives in skin rejuvenation.

\begin{tabular}{|c|c|c|c|c|c|c|c|c|}
\hline $\begin{array}{l}\text { First Author and } \\
\text { Year }\end{array}$ & Type of Study & PS & Chemical Family & Concentration (PS) & Pre-Irradiation Time & LIGHT SOURCE & Dose of Light & Results \\
\hline $\begin{array}{l}\text { Clementoni et al., } \\
2010\end{array}$ & Clinical & ALA & Porphyrin & $20 \%$ & $1 \mathrm{~h}$ & $\begin{array}{l}\text { Broadband Pulsed Light } \\
560 \mathrm{~nm} \text { and LED } 630 \mathrm{~nm} \text { and }\end{array}$ & $\begin{array}{l}19-22 \mathrm{~J} / \mathrm{cm}^{2} \text { and } 75 \\
\mathrm{~J} / \mathrm{cm}^{2}\end{array}$ & $\begin{array}{l}\text { Moderate improvement in fine lines, tactile roughness and } \\
\text { firmness of the skin was observed in most patients. }\end{array}$ \\
\hline Xi et al., 2011 & Clinical & ALA & Porphyrin & $5 \%$ and $10 \%$ & $1 \mathrm{~h}$ & IPL $520-1200 \mathrm{~nm}$ & $\begin{array}{l}14-20 \mathrm{~J} / \mathrm{cm}^{2} \text { or } 17- \\
20 \mathrm{~J} / \mathrm{cm}^{2}\end{array}$ & $\begin{array}{l}\text { ALA-IPL has better efficacy in the skin rejuvenation of } \\
\text { Chinese patients than IPL alone. }\end{array}$ \\
\hline Jang et al., 2013 & In vitro & ALA & Porphyrin & $0.05-1 \mathrm{mM}$ & $30 \mathrm{~min}$. & Incoherente light $633 \mathrm{~nm}$ & $3-10 \mathrm{~J} / \mathrm{cm}^{2}$ & $\begin{array}{l}\text { Intracellular EROs stimulated by PDT in dermal } \\
\text { fibroblasts lead to the prolonged activation of ERK } \\
\text { contributing to the effect of rejuvenation in PDT. }\end{array}$ \\
\hline Ji et al., 2014 & Clinical & ALA & Porphyrin & 5,10 , and $20 \%$ & $2 \mathrm{~h}$ & LED $630 \mathrm{~nm}$ & $90 \mathrm{~J} / \mathrm{cm}^{2}$ & $\begin{array}{l}\text { ALA-PDT was better than red light for skin } \\
\text { rejuvenation. }\end{array}$ \\
\hline Zhang et al., 2014 & Clinical & ALA & Porphyrin & $5 \%$ & $2 \mathrm{~h}$ & $\begin{array}{l}\text { Intense pulsed laser } \\
550-570 \mathrm{~nm} \text { and LED } 630 \mathrm{~nm}\end{array}$ & $60 \mathrm{~J} / \mathrm{cm}^{2}$ & $\begin{array}{l}\text { PDT combining two light sources was better for } \\
\text { rejuvenation than the use of an individual light. }\end{array}$ \\
\hline $\begin{array}{l}\text { Friedmann et al., } \\
\quad 2015\end{array}$ & Clinical & ALA & Porphyrin & $20 \%$ & $1 \mathrm{~h}$ & $\begin{array}{l}\text { Red light } 635 \mathrm{~nm} \text {, blue light } \\
417 \mathrm{~nm} \text {, intense pulsed light } \\
560 \mathrm{~nm} \text {, pulsed dye laser } 595 \mathrm{~nm}\end{array}$ & $\begin{array}{c}10,37,(15-22) \\
6.5-8 \mathrm{~J} / \mathrm{cm}^{2}\end{array}$ & $\begin{array}{l}\text { No significant differences in skin rejuvenation and adverse } \\
\text { effects were reported among the evaluated } \\
\text { groups (blue light + PDL)/(blue light + IPL)/(blue light + PDL } \\
+ \text { IPL)/(blue light + red light + PDL + IPL). }\end{array}$ \\
\hline Shin et al., 2015 & Clinical & ALA & Porphyrin & $0.5 \%$ & $\begin{array}{l}\text { Applications at } 5 \text {-min } \\
\text { intervals for one hour }\end{array}$ & $\begin{array}{l}\text { Intense pulsed light } \\
(400-720 \mathrm{~nm}) \text { and long pulsed Nd: } \\
\text { YAG laser }\end{array}$ & $\begin{array}{l}10.5 \mathrm{~J} / \mathrm{cm}^{2} \text { and } 61.8- \\
83.9 \mathrm{~J} / \mathrm{cm}^{2}\end{array}$ & $\begin{array}{l}\text { Liposomal spray-PDT reduced wrinkles without side effects, } \\
\text { suggesting it as a promising alternative treatment for } \\
\text { wrinkles in Asians. }\end{array}$ \\
\hline Zhou et al., 2016 & In vitro & ALA & Porphyrin & $\begin{array}{l}0.25,0.50,1.00 \text { or } \\
2.00 \mathrm{mmol} / \mathrm{L}\end{array}$ & $2 \mathrm{~h}$ or $6 \mathrm{~h}$ & laser $635 \mathrm{~nm}$ & 25,50 e $100 \mathrm{~J} / \mathrm{cm}^{2}$ & $\begin{array}{l}\text { ALA-PDT causes oxidative damage and apoptosis in vitro } \\
\text { in photoaged fibroblasts. This finding may be the basis for } \\
\text { the rejuvenating effects of PDT on photoaged skin. }\end{array}$ \\
\hline Kim et al., 2018 & Clinical & MAL & Porphyrin & $160 \mathrm{mg} / \mathrm{g}$ & $3 \mathrm{~h}$ & LED $630 \mathrm{~nm}$ & $37 \mathrm{~J} / \mathrm{cm}^{2}$ & $\begin{array}{l}\text { PDT reduced mottled hyperpigmentation in photo aged patient } \\
\text { skin, leading to skin whitening. }\end{array}$ \\
\hline
\end{tabular}




\section{Discussion and Future Perspectives}

The use of PDT allied to topical and nontoxic PSs has been explored in a number of different clinical applications not only for the treatment of inflammatory or infectious diseases, but also for skin rejuvenation [4]. This paper highlighted the clinical evidences and the usefulness of the three classes of PSs, chlorins, phthalocyanines, and porphyrins and their use in PDT and in fighting acne vulgaris, psoriasis, HPV-associated warts, and leishmaniasis. Moreover, PDT can open an avenue in fighting bacterial drug resistance as can be depicted in studies of PDT on helping in prolonged acne remission $[4,30]$. PSs used in studies to suppress acne are mostly derived from porphyrin, such as ALA and MAL [36,37], and more recently the number of studies using chlorin derivatives, for example chlorin-e6 [38], has been increased. To date, work using phthalocyanines for this dermatological condition has not been observed, possibly due to the fact that this condition does not require a greater tissue penetration of the light made possible by this class of PS.

The introduction of ALA as PS has been considered as a major advance of PDT in dermatology. ALA is metabolized to PPIX via the heme biosynthetic pathway, which is common to all nucleated mammalian cells [120]. The accumulated excess of PPIX generates ROS after illumination, leading to apoptosis and necrosis of target tissue. This precursor is small enough to penetrate the skin barrier and can accumulate inside pilosebaceous units and hyperproliferative keratinocytes compared to normal skin, making the treatment selective [121]. In addition, in many pathological skin lesions, because the stratum corneum barrier is generally compromised, this might be further explored in order to increase the selectivity action of ALA due to its facilitated penetration. An additional advantage of PPIX refers to its photodegradation during irradiation, which means that its selective cytotoxic effect continues only during PDT application. However, despite the efficiency of this precursor in acne treatment, studies have shown that this option is painful and cause erythemas, edemas, bubbles, and transient hyperpigmentation, which requires further studies in order to determine the right dosage of both light and PSs [122].

The prodrug MAL, an ALA derivative, is more lipophilic, allowing a greater tissue penetration than ALA. Although the MAL PS chlorin-e6 has shown interesting results in in vitro and in vivo models of acne vulgaris [4,38], further studies are necessary in order to confirm its efficacy, including studies on biofilms, which are poorly explored in the literature and will define better parameters for its implementation in clinical protocols.

As for psoriasis, studies were performed using porphyrin derivative such as ALA and phthalocyanine derivatives [66,67]. Studies using chlorin for this disorder have not been observed so far. The efficacy of PDT in the treatment of psoriasis is still controversial in the literature. Studies have shown that the use of ALA may be effective; however, it may show adverse effects making it difficult to be tolerated by patients [70]. Thus, studies involving lower concentrations of the drugs as well as the association with low doses of light and even the use of other PSs may be necessary for the success of PDT to be confirmed in the treatment of psoriasis.

In the treatments for warts caused by HPV infection, ALA also excels in photodynamic treatment due to the antiviral properties of this therapy [78]. Although PDT was successful in this application, pain during irradiation still hampers the widespread use of this treatment modality [123].

The main studies involving the use of porphyrins in the treatment of cutaneous leishmaniasis use ALA as PS, but a study conducted by Sah et al. [124] has reported that the ALA-mediated PDT antiparasitic mechanism is probably due to the death of the infected host cells, and not through the death of the parasite because of the inability of these pathogens to produce PPIX, since the literature has reported that L. amazonensis is deficient of most of the enzymes that are part of the biosynthetic pathway of the heme group. Thus, the use of PSs having direct action onto parasite is interesting. Indeed, PSs such as chlorins and phthalocyanine have been explored in PDT for cutaneous leishmaniasis treatment. Chlorin-e6 might impair the parasite mitochondrial function, leading to the parasite death, since this unique organelle is involved in many vital mechanisms, such as calcium homeostasis [125]. Another interesting approach is the combination of the PDT and the use of current antileishmanial drugs. In this context, Ribeiro et al. [103] developed an AlCIPC and combined it with the drug miltefosine to evaluate the synergistic effect, which showed high leishmanicidal activity.

As for skin rejuvenation, the use of PDT in the area of esthetics has shown good results, showing an improvement in the appearance of the skin in the treated area and low side effects, causing much interest for the scientific community in clinical studies. Although the most employed PSs for this purpose used so far are the porphyrin derivatives ALA and MAL. A recent study [53] has shown that chlorin-e6-mediated PDT may be promising in cosmetic area since this therapy has been able to increase collagen I production, which may help 
both in the skin rejuvenation process as well as to minimize the scars caused by severe acne. Thus, chlorin-e6 can be in a near future a multi-task PSs, useful not only in facial rejuvenation, but also in the treatment of inflammatory diseases [38].

In summary, this review showed that although many reports have been published in recent years using PDT and its application in several skin-related diseases, new studies are need in order to understand the immune system response of the patient after the treatment, using more accurate assessment and standardization of preirradiation time, light dosimetry, and type of light source. Besides, PSs must have lower toxicity, being possible to evaluate studies with lower concentrations and larger numbers of photodynamic applications. Finally, the combination of PDT and nanotechnology

will certainly improve the properties of these PSs as well as their action in photodynamic treatment, allowing the establishment of newer, safer, and more efficient protocols to be used in the clinical practice.

\section{References}

1. Seidel, R. W.; Oppel, I. M., 1D and 2D solid-state metallosupramolecular arrays of freebase 5,10,15,20-tetra(4-pyridyl)porphyrin, peripherally linked by zinc and manganese ions. Structural Chemistry 2009, 20 (1), 121-128.

2. Seidel, R. W.; Oppel, I. M., 2D Metallosupramolecular Arrays of Zinc-5,10,15,20-tetra(4pyridyl)porphyrin via Self-complementary Coordination and Peripheral Linkage. Zeitschrift Fur Anorganische Und Allgemeine Chemie 2010, 636 (3-4), 446-448.

3. Han, C.; Shao, Q.; Liu, M.; Ge, S. S.; Liu, Q. Y.; Lei, J., 5,10,15,20-tetrakis(4-

chlorophenyl)porphyrin decorated $\mathrm{TiO} 2$ nanotube arrays: Composite photoelectrodes for visible photocurrent generation and simultaneous degradation of organic pollutant. Materials Science in Semiconductor Processing 2016, 56, 166-173.

4. $\quad$ Li, A.; Zhao, L. Z.; Hao, J.; Ma, R. J.; An, Y. L.; Shi, L. Q., Aggregation Behavior of the Template-Removed 5,10,15,20-Tetrakis(4-sulfonatophenyl)porphyrin Chiral Array Directed by Poly(ethylene glycol)-block-poly(L-lysine). Langmuir 2014, 30 (16), 4797-4805.

5. Wang, R. B.; Brugh, A. M.; Rawson, J.; Therien, M. J.; Forbes, M. D. E., Alkyne-Bridged Multi[Copper(II) Porphyrin] Structures: Nuances of Orbital Symmetry in Long-Range, Through-Bond Mediated, Isotropic Spin Exchange Interactions. Journal of the American Chemical Society 2017, 139 (29), 9759-9762.

6. Li, Z. Z.; Sinha, S.; Treich, G. M.; Wang, Y. F.; Yang, Q. W.; Deshmukh, A.; Sotzing, G. A.; Cao, Y., All-organic flexible fabric antenna for wearable electronics. Journal of Materials Chemistry C 2020, 8 (17), 5662-5667.

7. Ogawa, T., Analysis of Single Molecule Conductance of Heterogeneous Porphyrin Arrays by Partial Transmission Probabilities. Chemistryselect 2017, 2 (25), 7483-7483.

8. Tamaki, T.; Ohto, T.; Yamada, R.; Tada, H.; Ogawa, T., Analysis of Single Molecule Conductance of Heterogeneous Porphyrin Arrays by Partial Transmission Probabilities. Chemistryselect 2017, 2 (25), 74847488 .

9. Leng, X. B.; Choi, C. F.; Lo, P. C.; Ng, D. K. P., Assembling a mixed phthalocyanine-porphyrin array in aqueous media through host-guest interactions. Organic Letters 2007, 9 (2), 231-234.

10. Gehrold, A. C.; Bruhn, T.; Bringmann, G., Axial, Helical, and Planar Chirality in Directly Linked Basket-Handle Porphyrin Arrays. Journal of Organic Chemistry 2016, 81 (3), 1075-1088.

11. Mulay, S. V.; Bogoslavky, B.; Galanti, I.; Galunc, E.; Gidron, O., Bifuran-imide: a stable furan building unit for organic electronics. Journal of Materials Chemistry C 2018, 6 (44), 11951-11955.

12. Zhang, J. X.; Wu, Y.; Liu, J. C.; Li, R. Z., Bilayer structured supramolecular light harvesting arrays based on zinc porphyrin coordination polymers for enhanced photocurrent generation in dye sensitized solar cells. Dalton Transactions 2016, 45 (41), 16283-16289.

13. Wang, Y., Biomimetic, wearable organic electronics via 3D printing. Abstracts of Papers of the American Chemical Society 2018, 256.

14. Gamage, P.; Fiedler, A.; Stefan, M.; Biewer, M., Bipyrimidine based donor-acceptor conjugated polymers for organic electronics. Abstracts of Papers of the American Chemical Society 2018, 256.

15. Kuklin, S. A.; Konstantinov, I. O.; Peregudov, A. S.; Ostapov, I. E.; Makhaeva, E. E.; Khokhlov, A. R.; Keshtov, M. L., Bis[1,3]thiazolo[4,5-f:5',4'-h]thieno[3,4-b]quinoxaline Derivatives as New Building Blocks of Polymers for Organic Electronics. Doklady Chemistry 2018, 482, 207-211.

16. Zhang, X. N.; Wang, B. H.; Huang, L. Z.; Huang, W.; Wang, Z.; Zhu, W. G.; Chen, Y.; Mao, Y. L.; Facchetti, A.; Marks, T. J., Breath figure-derived porous semiconducting films for organic electronics.

Science Advances 2020, 6 (13). 
17. Franzke, Y. J.; Sundholm, D.; Weigendb, F., Calculations of current densities and aromatic pathways in cyclic porphyrin and isoporphyrin arrays. Physical Chemistry Chemical Physics 2017, 19 (20), 1279412803.

18. Hamad, W., Cellulose nanocrystals in organic electronics. Abstracts of Papers of the American Chemical Society 2018, 256.

19. Zhang, C. F.; Chen, M.; Qian, D. J., Characterization and electrochemistry of interfacial selfassembled multi-manganese (III)-porphyrin arrays. Thin Solid Films 2009, 517 (13), 3760-3765.

20. Goodenough, I.; Rawson, J.; Angiolillo, P.; Therien, M., Charge accommodation in n-doped ethynyl-bridged pi-conjugated porphyrin arrays. Abstracts of Papers of the American Chemical Society 2016, 252.

21. Calvo, J. J.; Angel, S. M.; So, M. C., Charge transport in metal-organic frameworks for electronics applications. Apl Materials 2020, 8 (5).

22. Paolesse, R.; Lvova, L.; Nardis, S.; Di Natale, C.; D'Amico, A.; Lo Castro, F., Chemical images by porphyrin arrays of sensors. Microchimica Acta 2008, 163 (1-2), 103-112.

23. Cho, W. J.; Cho, Y.; Min, S. K.; Kim, W. Y.; Kim, K. S., Chromium Porphyrin Arrays As Spintronic Devices. Journal of the American Chemical Society 2011, 133 (24), 9364-9369.

24. Lee, M.; Kim, H.; Kim, D.; Sim, E., Coherence length determination of meso-meso linked porphyrin arrays based on forward-backward pair trajectory analysis. Journal of Physical Chemistry A 2008, $112(23), 5040-5045$.

25. Lee, M.; Kim, H.; Kim, D.; Sim, E., Coherent excitation energy transfer of meso-meso linked porphyrin array. 2007 Pacific Rim Conference on Lasers and Electro-Optics, Vols 1-4 2007, 1388-1389.

26. Liu, Y.; Ke, C. F.; Zhang, H. Y.; Cui, J.; Ding, F., Complexation-induced transition of nanorod to network aggregates: Alternate porphyrin and cyclodextrin arrays. Journal of the American Chemical Society 2008, 130 (2), 600-605.

27. Magna, G.; Catini, A.; Kumar, R.; Palmacci, M.; Martinelli, E.; Paolesse, R.; di Natale, C., Conductive Photo-Activated Porphyrin-ZnO Nanostructured Gas Sensor Array. Sensors 2017, 17 (4).

28. Wang, M.; Baek, P.; Akbarinejad, A.; Barker, D.; Travas-Sejdic, J., Conjugated polymers and composites for stretchable organic electronics. Journal of Materials Chemistry C 2019, 7 (19), 5534-5552.

29. Tanaka, T.; Osuka, A., Conjugated porphyrin arrays: synthesis, properties and applications for functional materials. Chemical Society Reviews 2015, 44 (4), 943-969.

30. Crossley, M. J.; Sheehan, C. S.; Khoury, T.; Reimers, J. R.; Sintic, P. J., Construction of building blocks for extended porphyrin arrays by nitration of porphyrin-2,3-diones and quinoxalino[2,3-b]porphyrins. New Journal of Chemistry 2008, 32 (2), 340-352.

31. Iritani, K.; Tahara, K.; Hirose, K.; De Feyter, S.; Tobe, Y., Construction of cyclic arrays of Znporphyrin units and their guest binding at the solid-liquid interface. Chemical Communications 2016, 52 (100), 14419-14422.

32. Hutchison, J. A.; Sintic, P. J.; Brotherhood, P. R.; Scholes, C.; Blake, I. M.; Ghiggino, K. P.; Crossley, M. J., Control of Photoinduced Charge Transfer Lifetimes in Porphyrin Arrays by Ligand Addition. Journal of Physical Chemistry C 2009, 113 (27), 11796-11804.

33. Ma, L. C.; Dai, S. X.; Zhan, X. W.; Liu, X. Y.; Li, Y., Convenient fabrication of conjugated polymer semiconductor nanotubes and their application in organic electronics. Royal Society Open Science 2018, 5 (8).

34. Trinh, T. M. N.; Nierengarten, I.; Ben Aziza, H.; Meichsner, E.; Holler, M.; Chesse, M.; Abidi, R.; Bijani, C.; Coppel, Y.; Maisonhaute, E.; Delavaux-Nicot, B.; Nierengarten, J. F., Coordination-Driven Folding in Multi-Zn-II-Porphyrin Arrays Constructed on a Pillar[5]arene Scaffold. Chemistry-a European Journal 2017, 23 (46), 11011-11021.

35. Capuano, R.; Pomarico, G.; Paolesse, R.; Di Natale, C., Corroles-Porphyrins: A Teamwork for Gas Sensor Arrays. Sensors 2015, 15 (4), 8121-8130.

36. Bernhard, S. S. R.; Locke, G. M.; Plunkett, S.; Meindl, A.; Flanagan, K. J.; Senge, M. O., Cubane Cross-Coupling and Cubane-Porphyrin Arrays. Chemistry-a European Journal 2018, 24 (5), 1026-1030.

37. Nakamura, Y.; Aratani, N.; Osuka, A., Cyclic porphyrin arrays as artificial photosynthetic antenna: Synthesis and excitation energy transfer. Chemical Society Reviews 2007, 36 (6), 831-845.

38. Muftakhov, M. V.; Khatymov, R. V.; Tuktarov, R. F., Decomposition of Aromatic Compounds Relevant to Organic Electronics under Exposure to Low-Energy Electrons. Technical Physics 2018, 63 (12), 1854-1860.

39. Yang, J. S.; Yoo, H.; Aratani, N.; Osuka, A.; Kim, D., Determination of the Superradiance Coherence Length of Directly Linked Linear Porphyrin Arrays at the Single-Molecule Level. Angewandte Chemie-International Edition 2009, 48 (24), 4323-4327. 
40. Ham, S.; Lee, J. E.; Song, S.; Peng, X. B.; Hori, T.; Aratani, N.; Osuka, A.; Sim, E.; Kim, D., Direct observation of structural properties and fluorescent trapping sites in macrocyclic porphyrin arrays at the single-molecule level. Physical Chemistry Chemical Physics 2016, 18 (5), 3871-3877.

41. Song, C. H.; Back, S. Y.; Yu, S. I.; Lee, H. J.; Kim, B. S.; Yang, N. Y.; Jeong, S. H.; Ahn, H., Direct-Patterning of Porphyrin Dot Arrays and Lines Using Electrohydrodynamic Jet Printing. Journal of Nanoscience and Nanotechnology 2012, 12 (1), 475-480.

42. Aratani, N.; Kim, D.; Osuka, A., Discrete Cyclic Porphyrin Arrays as Artificial Light-Harvesting Antenna. Accounts of Chemical Research 2009, 42 (12), 1922-1934.

43. Fendt, L. A.; Bouamaied, I.; Thoni, S.; Amiot, N.; Stulz, E., DNA as supramolecular scaffold for porphyrin arrays on the nanorneter scale. Journal of the American Chemical Society 2007, 129 (49), 1531915329.

44. $\quad$ Payne, A. J.; Rice, N. A.; McAfee, S. M.; Lo, S.; Josse, P.; Cabanetos, C.; Risko, C.; Lessard, B. H.; Welch, G. C., Donor or Acceptor? How Selection of the Rylene Imide End Cap Impacts the Polarity of piConjugated Molecules for Organic Electronics. Acs Applied Energy Materials 2018, 1 (9), 4906-4916.

45. Fujimoto, J.; Manseki, K.; Miyaji, H., Dye-sensitized Solar Cells Using Supramolecular Porphyrin Arrays Inspired by pi-Stacking Structures of Photosynthetic Light-harvesting Complexes. Chemistry Letters 2014, 43 (2), 207-209.

46. Luo, L.; Lin, C. J.; Tsai, C. Y.; Wu, H. P.; Li, L. L.; Lo, C. F.; Lin, C. Y.; Diau, E. W. G., Effects of aggregation and electron injection on photovoltaic performance of porphyrin-based solar cells with oligo(phenylethynyl) links inside TiO2 and Al2O3 nanotube arrays. Physical Chemistry Chemical Physics 2010, 12 (5), 1064-1071.

47. Bin, Z. Y.; Liu, Z. Y.; Qiu, Y.; Duan, L., Efficient n-Dopants and Their Roles in Organic Electronics. Advanced Optical Materials 2018, 6 (18).

48. Sugawa, K.; Yamaguchi, D.; Tsunenari, N.; Uchida, K.; Tahara, H.; Takeda, H.; Tokuda, K.; Jin, S.; Kusaka, Y.; Fukuda, N.; Ushijima, H.; Akiyama, T.; Watanuki, Y.; Nishimiya, N.; Otsuki, J.; Yamada, S., Efficient Photocurrent Enhancement from Porphyrin Molecules on Plasmonic Copper Arrays: Beneficial Utilization of Copper Nanoanntenae on Plasmonic Photoelectric Conversion Systems. Acs Applied Materials \& Interfaces 2017, 9 (1), 750-762.

49. Ouyang, Q.; Zhu, Y. Z.; Zhang, C. H.; Yan, K. Q.; Li, Y. C.; Zheng, J. Y., An Efficient PIFAMediated Synthesis of Fused Diporphyrin and Triply-Singly Interlacedly Linked Porphyrin Array. Organic Letters 2009, 11 (22), 5266-5269.

50. Souto, M.; Strutynski, K.; Melle-Franco, M.; Rocha, J., Electroactive Organic Building Blocks for the Chemical Design of Functional Porous Frameworks (MOFs and COFs) in Electronics. Chemistry-a European Journal 2020.

51. Tabbi, G.; Di Mauro, G.; Purrello, R.; Bonomo, R. P., Electrochemical characterization of ordered arrays of metallo-porphyrins in aqueous solution. Dalton Transactions 2011, 40 (16), 4223-4229.

52. Kim, J.; Yamamoto, K.; Iimura, S.; Ueda, S.; Hosono, H., Electron Affinity Control of Amorphous Oxide Semiconductors and Its Applicability to Organic Electronics. Advanced Materials Interfaces 2018, 5 (23).

53. Cho, S.; Yoon, M. C.; Kim, K. S.; Kim, P.; Kim, D., Electron delocalization in various triply linked zinc(II) porphyrin arrays: role of antiaromatic junctions between aromatic porphyrins. Physical Chemistry Chemical Physics 2011, 13 (36), 16175-16181.

54. Rawson, J.; Angiolillo, P. J.; Frail, P. R.; Goodenough, I.; Therien, M. J., Electron Spin Relaxation of Hole and Electron Polarons in pi-Conjugated Porphyrin Arrays: Spintronic Implications. Journal of Physical Chemistry B 2015, 119 (24), 7681-7689.

55. Lazarides, T.; Kuhri, S.; Charalambidis, G.; Panda, M. K.; Guldi, D. M.; Coutsolelos, A. G., Electron vs Energy Transfer in Arrays Featuring Two Bodipy Chromophores Axially Bound to a Sn(IV) Porphyrin via a Phenolate or Benzoate Bridge. Inorganic Chemistry 2012, 51 (7), 4193-4204.

56. High, J. S.; Virgil, K. K.; Jakubikova, E., Electronic Structure and Absorption Properties of Strongly Coupled Porphyrin-Perylene Arrays. Journal of Physical Chemistry A 2015, 119 (38), 9879-9888.

57. Jiang, H.; Hu, W. P., The Emergence of Organic Single-Crystal Electronics. Angewandte ChemieInternational Edition 2020, 59 (4), 1408-1428.

58. Zvezdin, A.; Di Mauro, E.; Rho, D.; Santato, C.; Khalil, M., En route toward sustainable organic electronics. Mrs Energy \& Sustainability 2020, 7.

59. Zhu, P. H.; Wang, P. P.; Kan, T. L.; Sun, G. Q.; Zhang, Y.; Yu, J. H., An enhanced photoelectrochemical immunosensing platform: Supramolecular donor-acceptor arrays by assembly of porphyrin and C-60. Biosensors \& Bioelectronics 2015, 68, 604-610. 
60. Novikov, A. V.; Kuznetsova, L. I.; Dremova, N. N.; Parfenov, A. A.; Troshin, P. A., Environmentfriendly aqueous processing of [60]fullerene semiconducting films for truly green organic electronics. Journal of Materials Chemistry C 2020, 8 (2), 495-499.

61. Li, J. L.; Cao, J. J.; Duan, L. L.; Zhang, H. L., Evolution of Isoindigo-Based Electron-Deficient Units for Organic Electronics: From Natural Dyes to Organic Semiconductors. Asian Journal of Organic Chemistry 2018, 7 (11), 2147-2160.

62. Rawson, J.; Angiolillo, P. J.; Therien, M. J., Exceptional delocalization of electrons in conjugated porphyrin arrays. Abstracts of Papers of the American Chemical Society 2012, 244.

63. Yang, J.; Park, M.; Yoon, Z. S.; Hori, T.; Peng, X. B.; Aratani, N.; Dedecker, P.; Hotta, J. I.; Uji-I, H.; Sliwa, M.; Hofkens, J.; Osuka, A.; Kim, D., Excitation energy migration processes in cyclic porphyrin Arrays probed by single molecule spectroscopy. Journal of the American Chemical Society 2008, 130 (6), 1879-1884.

64. Kim, P.; Ikeda, T.; Lim, J. M.; Park, J.; Lim, M.; Aratani, N.; Osuka, A.; Kim, D., Excited-state energy relaxation dynamics of triply linked $\mathrm{Zn}(\mathrm{II})$ porphyrin arrays. Chemical Communications 2011, 47 (15), 4433-4435.

65. Kim, T.; Oh, J.; Jiang, H. W.; Tanaka, T.; Osuka, A.; Kim, D., Exciton coupling dynamics in synand anti-type beta-beta linked Zn(II) porphyrin linear arrays. Physical Chemistry Chemical Physics 2016, 18 (33), 23105-23110.

66. Hori, T.; Nakamura, Y.; Aratani, N.; Osuka, A., Exploration of electronically interactive cyclic porphyrin arrays. Journal of Organometallic Chemistry 2007, 692 (1-3), 148-155.

67. Aratani, N.; Osuka, A., Exploration of Giant Functional Porphyrin Arrays. Bulletin of the Chemical Society of Japan 2015, 88 (1), 1-27.

68. Titi, H. M.; Nandi, G.; Tripuramallu, B. K.; Goldberg, I., Exploring Supramolecular Self-Assembly of Tetraarylporphyrins by Halogen Interactions. 3. Tin(L)(2)(A(2)B(2)-Porphyrin) Arrays Supported by Concerted Halogen and Hydrogen Bonding. Crystal Growth \& Design 2015, 15 (6), 3063-3075.

69. Luzanov, A. V., Extended quasi-correlated orbitals with long-range effects: Application to organic single-molecule electronics. Functional Materials 2020, 27 (1), 147-158.

70. Sugawa, K.; Uchida, K.; Takeshima, N.; Jin, S.; Tsunenari, N.; Takeda, H.; Kida, Y.; Akiyama, T.; Otsuki, J.; Takase, K.; Yamada, S., Extraordinary enhancement of porphyrin photocurrent utilizing plasmonic silver arrays. Nanoscale 2016, 8 (34), 15467-15472.

71. Sanchez-Vergara, M. E.; Guevara-Martinez, E.; Arreola-Castillo, A.; Mendoza-Sevilla, A., Fabrication of Hybrid Membranes Containing Nylon-11 and Organic Semiconductor Particles with Potential Applications in Molecular Electronics. Polymers 2020, 12 (1).

72. La, D. D.; Thi, H. P. N.; Kim, Y. S.; Rananaware, A.; Bhosale, S. V., Facile fabrication of Cu(II)porphyrin MOF thin films from tetrakis(4-carboxyphenyl) porphyrin and $\mathrm{Cu}(\mathrm{OH})(2)$ nanoneedle array. Applied Surface Science 2017, 424, 145-150.

73. Slodek, A.; Zych, D.; Maron, A.; Golba, S.; Schab-Balcerzak, E.; Janeczek, H.; Siwy, M.; Mackowski, S., Fluorene vs carbazole substituent at quinoline core toward organic electronics. Dyes and Pigments 2019, 166, 98-106.

74. Kose, K.; Motoyanagi, J.; Kusukawa, T.; Osuka, A.; Tsuda, A., Formation of Discrete Ladders and a Macroporous Xerogel Film by the Zipperlike Dimerization of Meso-Meso-Linked Zinc(II) Porphyrin Arrays with Di(pyrid-3-yl)acetylene. Angewandte Chemie-International Edition 2015, 54 (30), 8673-8678.

75. Yoshimoto, S.; Sato, K.; Sugawara, S.; Chen, Y.; Ito, O.; Sawaguchi, T.; Niwa, O.; Itaya, K., Formation of supramolecular nanobelt arrays consisting of cobalt(II) "Picket-Fence" porphyrin on Au surfaces. Langmuir 2007, 23 (2), 809-816.

76. Zenkevich, E. I.; von Borczyskowski, C. W., Formation Principles and Excited States Relaxation in Self-Assembled Complexes: Multiporphyrin Arrays and "Semiconductor CdSe/ZnS Quantum Dot-Porphyrin" Nanocomposites. Handbook of Porphyrin Science with Applications to Chemistry, Physics, Materials Science, Engineering, Biology and Medicine, Vol 22: Biophysical and Physicochemical Studies of Tetrapyrroles 2012, $22,67-168$.

77. Urbani, M.; Iehl, J.; Osinska, I.; Louis, R.; Holler, M.; Nierengarten, J. F., Formyl-Porphyrin and Formyl-Fullerenoporphyrin Building Blocks for the Construction of Multiporphyrin Arrays. European Journal of Organic Chemistry 2009, (22), 3715-3725.

78. Sariciftci, N. S., From Organic Electronics to Bio-organic Electronics. Nonlinear Optics Quantum Optics-Concepts in Modern Optics 2019, 50 (1-3), 137-144.

79. D'Urso, A.; Fragala, M. E.; Purrello, R., From self-assembly to noncovalent synthesis of programmable porphyrins' arrays in aqueous solution. Chemical Communications 2012, 48 (66), 8165-8176. 
80. Xu, M.; Pradhan, S.; Pal, R. K.; Yadavalli, V. K., Fully organic, flexible, and biodegradable components for bioinspired electronics. Micro- and Nanotechnology Sensors, Systems, and Applications Xi 2019, 10982.

81. AbdulAlmohsin, S.; Cui, J. B., Graphene-Enriched P3HT and Porphyrin-Modified ZnO Nanowire Arrays for Hybrid Solar Cell Applications. Journal of Physical Chemistry C 2012, 116 (17), 9433-9438.

82. Balogun, S. W.; James, O. O.; Sanusi, Y. K.; Olayinka, O. H., Green synthesis and characterization of zinc oxide nanoparticles using bashful (Mimosa pudica), leaf extract: a precursor for organic electronics applications. Sn Applied Sciences 2020, 2 (3).

83. Baciu, B. C.; de Ara, T.; Sabater, C.; Untiedt, C.; Guijarro, A., Helical nanostructures for organic electronics: the role of topological sulfur in ad hoc synthesized dithia[7]helicenes studied in the solid state and on a gold surface. Nanoscale Advances 2020, 2 (5), 1921-1926.

84. Chiba, Y.; Liu, M.; Tachibana, Y.; Fujihara, T.; Tsuji, Y.; Terao, J., Hetero Face-to-Face Porphyrin Array with Cooperative Effects of Coordination and Host-Guest Complexation. Chemistry-an Asian Journal 2017, 12 (15), 1900-1904.

85. Lo, P. C.; Leng, X. B.; Ng, D. K. P., Hetero-arrays of porphyrins and phthalocyanines. Coordination Chemistry Reviews 2007, 251 (17-20), 2334-2353.

86. Yoon, M. C.; Yoon, Z. S.; Cho, S.; Kim, D.; Takagi, A.; Matsumoto, T.; Kawai, T.; Hori, T.; Peng, X. B.; Aratani, N.; Osuka, A., A hexagonal prismatic porphyrin array: Synthesis, STM detection, and efficient energy hopping in near-infrared region. Journal of Physical Chemistry A 2007, 111 (38), 9233-9239. 87. Gumyusenge, A.; Mei, J. G., High Temperature Organic Electronics. Mrs Advances 2020, 5 (10), 505-513.

88. Saeki, A.; Kranthiraja, K., A high throughput molecular screening for organic electronics via machine learning: present status and perspective. Japanese Journal of Applied Physics 2020, 59.

89. Liu, Y. F.; Ding, T.; Chen, X. T.; Bai, F. Q.; Genco, A.; Wang, H. R.; Chen, C.; Chen, P.; Mazzeo, M.; Zhang, Y. T.; Duan, Y., Highly Conductive Alkaline-Earth Metal Electrodes: The Possibility of Maintaining Both Low Work Function and Surface Stability for Organic Electronics. Advanced Optical Materials 2020.

90. Yang, C.; Liu, Q. F.; Zang, L. M.; Qiu, J. H.; Wang, X.; Wei, C.; Qiao, X.; Hu, L.; Yang, J.; Song, G.; Liu, C. J., High-Performance Yarn Supercapacitor Based on Metal-Inorganic-Organic Hybrid Electrode for Wearable Electronics. Advanced Electronic Materials 2019, 5 (1).

91. Piotrowska, K.; Verdingovas, V.; Ambat, R., Humidity-related failures in electronics: effect of binary mixtures of weak organic acid activators. Journal of Materials Science-Materials in Electronics 2018, 29 (20), 17834-17852.

92. Zetola, N. M.; Modongo, C.; Matlhagela, K.; Sepako, E.; Matsiri, O.; Tamuhla, T.; Mbongwe, B.; Martinelli, E.; Sirugo, G.; Paolesse, R.; Di Natale, C., Identification of a Large Pool of Microorganisms with an Array of Porphyrin Based Gas Sensors. Sensors 2016, 16 (4).

93. Singh, A. K.; Chou, W. F.; Jia, X. J.; Wang, C. Y.; Fuentes-Hernandez, C.; Kippelen, B.; Graham, S., Impact of interface materials on side permeation in indirect encapsulation of organic electronics. Journal of Vacuum Science \& Technology A 2020, 38 (3).

94. Bronshtein, I.; Leitus, G.; Rybtchinski, B., In Situ Growth of High Quality Crystals for Organic Electronics. Acs Applied Electronic Materials 2020, 2 (3), 790-795.

95. Singleton, D. G.; Hussain, R.; Siligardi, G.; Kumar, P.; Hrdlicka, P. J.; Berova, N.; Stulz, E., Increased duplex stabilization in porphyrin-LNA zipper arrays with structure dependent exciton coupling. Organic \& Biomolecular Chemistry 2016, 14 (1), 149-157.

96. Zhang, L. J.; Jiang, X. X.; Jiang, W.; Li, S.; Chi, Y. X.; Liu, H.; Zhang, M. Y.; Li, J. Y.; Fang, M.; Pan, B.; Chen, Y. L.; Shen, C. N.; Guo, X.; Li, R.; Guo, L.; Su, Y. W., Infrared Skin-Like Active Stretchable Electronics Based on Organic-Inorganic Composite Structures for Promotion of Cutaneous Wound Healing. Advanced Materials Technologies 2019, 4 (8).

97. Brewer, A.; Siligardi, G.; Neylon, C.; Stulz, E., Introducing structural flexibility into porphyrinDNA zipper arrays. Organic \& Biomolecular Chemistry 2011, 9 (3), 777-782.

98. Brewer, A.; Siligardi, G.; Neylon, C.; Stulz, E., Introducing structural flexibility into porphyrinDNA zipper arrays (vol 9, pg 777, 2011). Organic \& Biomolecular Chemistry 2011, 9 (24), 8505-8506.

99. Jiang, Y.; Qin, D. D.; Fan, Y. R.; Guo, H. X.; Wang, S. X.; Ning, X. M.; Lu, X. Q., Investigation of photoinduced electron transfer on $\mathrm{TiO} 2$ nanowire arrays/porphyrin composite via scanning electrochemical microscopy. Rsc Advances 2015, 5 (70), 56697-56703.

100. Romele, P.; Ghittorelli, M.; Kovacs-Vajna, Z. M.; Torricelli, F., Ion buffering and interface charge enable high performance electronics with organic electrochemical transistors. Nature Communications 2019, 10. 
101. Muresan, A. Z.; Holten, D.; Bocian, D. F.; Lindsey, J. S., Isotopically labeled porphyrins for studies of ground-state hole transfer in multiporphyrin arrays. Abstracts of Papers of the American Chemical Society 2007, 234 .

102. Kozaki, M.; Uetomo, A.; Suzuki, S.; Okada, K., A Light-Harvesting Array Composed of Porphyrins and Rigid Backbones. Organic Letters 2008, 10 (20), 4477-4480.

103. Kim, J. W.; Jang, Y. H.; Ku, G. M.; Kim, S.; Lee, E.; Cho, K.; Lim, K. I.; Lee, W. H., Liquid coplanar-gate organic/graphene hybrid electronics for label-free detection of single and double-stranded DNA molecules. Organic Electronics 2018, 62, 163-167.

104. Vollbrecht, J.; Oechsle, P.; Stepen, A.; Hoffmann, F.; Paradies, J.; Meyers, T.; Hilleringmann, U.; Schmidtke, J.; Kitzerow, H., Liquid crystalline dithienothiophene derivatives for organic electronics. Organic Electronics 2018, 61, 266-275.

105. Tajima, K., Look beyond the surface: recent progress in applications of surface-segregated monolayers for organic electronics. Polymer Journal 2019, 51 (11), 1117-1126.

106. Klain, C.; Linde, S.; Shikler, R.; Sarusi, G., Low work function Ca doped graphene as a transparent cathode for organic opto-electronics and OLEDs. Carbon 2020, 157, 255-261.

107. Bullard, G.; Tassinari, F.; Ko, C. H.; Mondal, A. K.; Wang, R.; Mishra, S.; Naaman, R.; Therien, M. J., Low-Resistance Molecular Wires Propagate Spin-Polarized Currents. Journal of the American Chemical Society 2019, 141 (37), 14707-14711.

108. Peng, X. B.; Huang, Y. Y.; Gao, C.; Peng, J. B.; Komatsu, N.; Osuka, A.; Cao, Y., Macroscopic Films of Porphyrin Nanowell-Arrays via Solvent Diffusion-Induced Self-Assembly. Journal of Physical Chemistry C 2010, 114 (43), 18449-18454.

109. Lee, J. H.; Jintoku, H.; Okazaki, Y.; Sagawa, T.; Takafuji, M.; Ihara, H., Manipulation of discrete porphyrin-fullerene nanopillar arrays regulated by the phase separated infiltration of polymer in ternary blended organic thin-films. Solar Energy Materials and Solar Cells 2015, 140, 428-438.

110. Mitra, K. Y.; Alalawe, A.; Voigt, S.; Boeffel, C.; Baumann, R. R., Manufacturing of All InkjetPrinted Organic Photovoltaic Cell Arrays and Evaluating Their Suitability for Flexible Electronics.

Micromachines 2018, 9 (12).

111. Teo, R. D.; Wang, R. B.; Smithwick, E. R.; Migliore, A.; Therien, M. J.; Beratan, D. N., Mapping hole hopping escape routes in proteins. Proceedings of the National Academy of Sciences of the United States of America 2019, 116 (32), 15811-15816.

112. Emandi, G.; Shaker, Y. M.; Flanagan, K. J.; O'Brien, J. M.; Senge, M. O., Merging Triptycene, BODIPY and Porphyrin Chemistry: Synthesis and Properties of Mono- and Trisubstituted Triptycene Dye Arrays. European Journal of Organic Chemistry 2017, (45), 6680-6692.

113. Thamyongkit, P.; Muresan, A. Z.; Diers, J. R.; Holten, D.; Bocian, D. F.; Lindsey, J. S., Meso-C13-labeled porphyrins for studies of ground-state hole transfer in multiporphyrin arrays. Journal of Organic Chemistry 2007, 72 (14), 5207-5217.

114. Mori, H.; Osuka, A., meso-meso Directly-linked trimeric and pentameric electron-deficient porphyrin-hexaphyrin hybrid arrays. Journal of Porphyrins and Phthalocyanines 2016, 20 (1-4), 245-253.

115. Mori, H.; Tanaka, T.; Lee, S.; Lim, J. M.; Kim, D.; Osuka, A., meso-meso Linked Porphyrin[26]Hexaphyrin-Porphyrin Hybrid Arrays and Their Triply Linked Tapes Exhibiting Strong Absorption Bands in the NIR Region. Journal of the American Chemical Society 2015, 137 (5), 2097-2106.

116. Zhang, S. M.; Kim, J. O.; Li, Y. J.; Wen, B.; Zhou, M. B.; Liu, S. B.; Aratani, N.; Xu, L.; Kim, D.; Song, J. X., meso-to-meso 2,5-Pyrrolylene bridged zig-zag porphyrin arrays. Chemical Communications 2017, 53 (83), 11488-11491.

117. Wu, J.; Chen, J. H.; Wang, C.; Zhou, Y.; Ba, K.; Xu, H.; Bao, W. Z.; Xu, X. H.; Carlsson, A.; Lazar, S.; Meingast, A.; Sun, Z. Z.; Deng, H. X., Metal-Organic Framework for Transparent Electronics. Advanced Science 2020, 7 (8).

118. Yu, J. X.; Mathew, S.; Flavel, B. S.; Quinton, J. S.; Johnston, M. R.; Shapter, J. G., Mixed assembly of ferrocene/porphyrin onto carbon nanotube arrays towards multibit information storage. 2008 International Conference on Nanoscience and Nanotechnology 2008, 176-179.

119. Santi, S.; Rossi, S., Molecular design of star-shaped benzotrithiophene materials for organic electronics. Tetrahedron Letters 2019, 60 (36).

120. Heo, J. H.; Ikeda, T.; Lim, J. M.; Aratani, N.; Osuka, A.; Kim, D., Molecular-Shape-Dependent Photophysical Properties of meso-beta Doubly Linked Zn(II) Porphyrin Arrays and Their Indene-Fused Analogues. Journal of Physical Chemistry B 2010, 114 (45), 14528-14536.

121. Abe, S.; Kobayashi, H.; Kiba, T.; Watari, F.; Sato, S. I., Morphology and Photophysical Properties of One-Dimensional Arrayed Porphyrin Aggregates Assisted by Cyclodextrin Inclusion Complexation. Molecular Crystals and Liquid Crystals 2012, 566, 151-157. 
122. Smith, A. R. G.; Ruggles, J. L.; Yu, A. M.; Gentle, I. R., Multilayer Nanostructured Porphyrin Arrays Constructed by Layer-by-Layer Self-Assembly. Langmuir 2009, 25 (17), 9873-9878.

123. Atefi, F.; McMurtrie, J. C.; Arnold, D. P., Multiporphyrin coordination arrays based on complexation of magnesium(II) porphyrins with porphyrinylphosphine oxides. Dalton Transactions 2007, (21), 2163-2170.

124. He, Z. R.; Zhang, Z. Y.; Bi, S., Nanoparticles for organic electronics applications. Materials Research Express 2020, 7 (1).

125. Cao, J.; Hu, D. C.; Liu, J. C.; Li, R. Z.; Jin, N. Z., Nanostructured TiO2 modified with acetohydrazide zinc porphyrin well-arrays for supramolecular solar cells. Organic Electronics 2014, 15 (2), 509-516.

126. Nowak-Krol, A.; Shoyama, K.; Stolte, M.; Wurthner, F., Naphthalene and perylene diimides - better alternatives to fullerenes for organic electronics? Chemical Communications 2018, 54 (98), 13763-13772.

127. Ariga, K.; Hill, J. P.; Wakayama, Y.; Akada, M.; Barrena, E.; de Oteyza, D. G., New aspects of porphyrins and related compounds: self-assembled structures in two-dimensional molecular arrays. Journal of Porphyrins and Phthalocyanines 2009, 13 (1), 22-34.

128. Caironi, M.; Muller, C.; von Hauff, E.; Sommer, M., New Materials for Organic Electronics: Improved Properties to Tackle Application Challenges. Advanced Electronic Materials 2018, 4 (10).

129. Buchner, F.; Seufert, K.; Auwarter, W.; Heim, D.; Barth, J. V.; Flechtner, K.; Gottfried, J. M.; Steinruck, H. P.; Marbach, H., NO-Induced Reorganization of Porphyrin Arrays. Acs Nano 2009, 3 (7), 1789 1794.

130. Korzec, M.; Kotowicz, S.; Rzycka-Korzec, R.; Schab-Balcerzak, E.; Malecki, J. G.; Czichy, M.; Lapkowski, M., Novel beta-ketoenamines versus azomethines for organic electronics: characterization of optical and electrochemical properties supported by theoretical studies. Journal of Materials Science 2020, 55 (9), 3812-3832.

131. Yutronkie, N. J.; Grant, T. M.; Melville, O. A.; Lessard, B. H.; Brusso, J. L., Old Molecule, New Chemistry: Exploring Silicon Phthalocyanines as Emerging N-Type Materials in Organic Electronics. Materials 2019, 12 (8).

132. Pirotte, G.; Verstappen, P.; Vanderzande, D.; Maes, W., On the "True" Structure of Push-Pull-Type Low-Bandgap Polymers for Organic Electronics. Advanced Electronic Materials 2018, 4 (10).

133. Ragni, R.; Punzi, A.; Babudri, F.; Farinola, G. M., Organic and Organometallic Fluorinated Materials for Electronics and Optoelectronics: A Survey on Recent Research. European Journal of Organic Chemistry 2018, 2018 (27-28), 3500-3519.

134. Goswami, S.; Goswami, S.; Venkatesan, T., An organic approach to low energy memory and brain inspired electronics. Applied Physics Reviews 2020, 7 (2).

135. Sinha, S.; Li, Z.; Noh, Y.; Chon, K.; Cao, Y.; Sotzing, G., Organic conductive polymers as printed electronics on fabrics for wearable electronics. Abstracts of Papers of the American Chemical Society 2019, 257.

136. Wang, Y.; Sun, L. J.; Wang, C.; Yang, F. X.; Ren, X. C.; Zhang, X. T.; Dong, H. L.; Hu, W. P., Organic crystalline materials in flexible electronics. Chemical Society Reviews 2019, 48 (6), 1492-1530.

137. Black, C.; Darie, R.; Borton, D., Organic Electronics for Artificial Touch. Trends in Neurosciences 2018, 41 (9), 568-570.

138. Seck, M.; Mohammadian, N.; Diallo, A. K.; Faraji, S.; Erouel, M.; Bouguila, N.; Ndiaye, D.; Khirouni, K.; Majewski, L. A., Organic FETs using biodegradable almond gum as gate dielectric: A promising way towards green electronics. Organic Electronics 2020, 83.

139. Ling, H. F.; Liu, S. H.; Zheng, Z. J.; Yan, F., Organic Flexible Electronics. Small Methods 2018, 2

(10).

140. Yu, K.; Rich, S.; Lee, S.; Fukuda, K.; Yokota, T.; Someya, T., Organic Photovoltaics: Toward Self-Powered Wearable Electronics. Proceedings of the Ieee 2019, 107 (10), 2137-2154.

141. Zhang, X. T.; Dong, H. L.; Hu, W. P., Organic Semiconductor Single Crystals for Electronics and Photonics. Advanced Materials 2018, 30 (44).

142. Lau, W. Y.; Hopkins, M., Organized arrays of functional molecules supported by gallium-porphyrin monolayers on HOPG. Abstracts of Papers of the American Chemical Society 2015, 249.

143. He, W. L.; Fang, F.; Ma, D. M.; Chen, M.; Qian, D. J.; Liu, M. H., Palladium-directed selfassembly of multi-titanium(IV)-porphyrin arrays on the substrate surface as sensitive ultrathin films for hydrogen peroxide sensing, photocurrent generation, and photochromism of viologen. Applied Surface Science 2018, 427, 1003-1010.

144. Hu, G. F.; Liu, R.; Alexy, E. J.; Mandal, A. K.; Bocian, D. F.; Holten, D.; Lindsey, J. S., Panchromatic chromophore-tetrapyrrole light-harvesting arrays constructed from Bodipy, perylene, terrylene, porphyrin, chlorin, and bacteriochlorin building blocks. New Journal of Chemistry 2016, 40 (9), 8032-8052. 
145. Ji, D. Y.; Li, T.; Fuchs, H., Patterning and applications of nanoporous structures in organic electronics. Nano Today 2020, 31.

146. Sakaguchi, K.; Kamimura, T.; Uno, H.; Mori, S.; Ozako, S.; Nobukuni, H.; Ishida, M.; Tani, F., Phenothiazine-Bridged Cyclic Porphyrin Dimers as High-Affinity Hosts for Fullerenes and Linear Array of C60 in Self-Assembled Porphyrin Nanotube. Journal of Organic Chemistry 2014, 79 (7), 2980-2992.

147. Popere, B. C.; Sanoja, G. E.; Thomas, E. M.; Schauser, N. S.; Jones, S. D.; Bartels, J. M.; Helgeson, M. E.; Chabinyc, M. L.; Segalman, R. A., Photocrosslinking polymeric ionic liquids via anthracene cycloaddition for organic electronics. Journal of Materials Chemistry C 2018, 6 (32), 8762-8769.

148. de Tacconi, N. R.; Chanmanee, W.; Rajeshwar, K.; Rochford, J.; Galoppini, E., Photoelectrochemical Behavior of Polychelate Porphyrin Chromophores and Titanium Dioxide Nanotube Arrays for Dye-Sensitized Solar Cells. Journal of Physical Chemistry C 2009, 113 (7), 2996-3006.

149. Yoon, M. C.; Noh, S. B.; Tsuda, A.; Nakamura, Y.; Osuka, A.; Kim, D., Photophysics of mesobeta doubly linked $\mathrm{Ni}(\mathrm{II})$ porphyrin arrays: Large two-photon absorption cross-section and fast energy relaxation dynamics. Journal of the American Chemical Society 2007, 129 (33), 10080-+.

150. Zhao, Q. D.; Yu, M.; Xie, T. F.; Peng, L. L.; Wang, P.; Wang, D. J., Photovoltaic properties of a $\mathrm{ZnO}$ nanorod array affected by ethanol and liquid-crystalline porphyrin. Nanotechnology 2008, 19 (24).

151. Alam, M. M.; Bolze, F.; Daniel, C.; Flamigni, L.; Gourlaouen, C.; Heitz, V.; Jenni, S.; Schmitt, J.; Sour, A.; Ventura, B., pi-Extended diketopyrrolopyrrole-porphyrin arrays: one- and two-photon photophysical investigations and theoretical studies. Physical Chemistry Chemical Physics 2016, 18 (31), 21954-21965.

152. Johnson, J. A.; Lin, Q. P.; Wu, L. C.; Obaidi, N.; Olson, Z. L.; Reeson, T. C.; Chen, Y. S.; Zhang, J., A "pillar-free", highly porous metalloporphyrinic framework exhibiting eclipsed porphyrin arrays.

Chemical Communications 2013, 49 (27), 2828-2830.

153. Mao, Y. Y.; Zhao, Q.; Pan, T. T.; Shi, J. Y.; Jiang, S. M.; Chen, M. W.; Zhou, B. P.; Tian, Y. Q., Platinum porphyrin/3-(trimethoxysily)propylmethacrylate functionalized flexible PDMS micropillar arrays as optical oxygen sensors. New Journal of Chemistry 2017, 41 (13), 5429-5435.

154. Wu, Y.; Liu, Y.; Emrick, T.; Russell, T. P., Polymer design to promote low work function surfaces in organic electronics. Progress in Polymer Science 2020, 103.

155. Yamamura, T.; Suzuki, S.; Taguchi, T.; Onoda, A.; Kamachi, T.; Okura, I., Porphyrin Arrays Responsive to Additives. Fluorescence Tuning. Journal of the American Chemical Society 2009, 131 (33), 11719-11726.

156. Ryan, A.; Gehrold, A.; Perusitti, R.; Pintea, M.; Fazekas, M.; Locos, O. B.; Blaikie, F.; Senge, M. O., Porphyrin Dimers and Arrays. European Journal of Organic Chemistry 2011, (29), 5817-5844.

157. Endo, M.; Fujitsuka, M.; Majima, T., Porphyrin light-harvesting arrays constructed in the recombinant tobacco mosaic virus scaffold. Chemistry-a European Journal 2007, 13 (31), 8660-8666.

158. Liu, Q. Y.; Zhu, J. Q.; Sun, T.; Zhou, H. Y.; Shao, Q.; Li, G. J.; Liu, X. D.; Yin, Y. S., Porphyrin nanotubes composed of highly ordered molecular arrays prepared by anodic aluminum template method. Rsc Advances 2013, 3 (8), 2765-2769.

159. Lvova, L.; Di Natale, C.; Paolesse, R., Porphyrin-based chemical sensors and multisensor arrays operating in the liquid phase. Sensors and Actuators B-Chemical 2013, 179, 21-31.

160. Bearinger, J. P.; Stone, G.; Dugan, L. C.; El Dasher, B.; Stockton, C.; Conway, J. W.; Kuenzler, T.; Hubbell, J. A., Porphyrin-based Photocatalytic Nanolithography A NEW FABRICATION TOOL FOR PROTEIN ARRAYS. Molecular \& Cellular Proteomics 2009, 8 (8), 1823-1831.

161. Maretina, I. A., Porphyrin-Ethynyl Arrays: Synthesis, Design, and Application. Russian Journal of General Chemistry 2009, 79 (7), 1544-1581.

162. Shirsat, M. D.; Sarkar, T.; Kakoullis, J.; Myung, N. V.; Konnanath, B.; Spanias, A.; Mulchandani, A., Porphyrin-Functionalized Single-Walled Carbon Nanotube Chemiresistive Sensor Arrays for VOCs. Journal of Physical Chemistry C 2012, 116 (5), 3845-3850.

163. Chen, J. P.; Aratani, N.; Shinokubo, H.; Osuka, A., Post-Modification of meso-meso-Linked Porphyrin Arrays by Iridium and Rhodium Catalyses for Tuning of Energy Gap. Chemistry-an Asian Journal 2009, 4 (7), 1126-1133.

164. Zenkevich, E.; von Borczyskowski, C., Primary Photoevents in Self-Assembled Complexes: Multiporphyrin Arrays and "Semiconductor CdSe/ZnS Nanocrystal-Porphyrin" Composites. Multiporphyrin Arrays: Fundamentals and Applications 2012, 217-288.

165. Mihara, N.; Yamada, Y.; Tanaka, K., Programmable Arrangement of Heterometal Ions in a Supramolecular Array of Porphyrin and Phthalocyanine. Bulletin of the Chemical Society of Japan 2017, 90 (4), 427-435.

166. Yang, X. U.; Zhang, D.; Tang, R. R.; Chen, X. H., Progress in the Synthesis and Application of Porphyrin-Perylene Arrays. Chinese Journal of Organic Chemistry 2009, 29 (12), 1906-1923. 
167. Minamiki, T.; Kubota, R.; Sasaki, Y.; Asano, K.; Minami, T., Protein Assays on Organic Electronics: Rational Device and Material Designs for Organic Transistor-Based Sensors. Chemistryopen 2020, 9 (5), 573-581.

168. Haft, M.; Knohl, S., PTS is a new Member of the OE-A (Organic and Printed Electronics Association) Network: New Opportunities \& Possibilities. Wochenblatt Fur Papierfabrikation 2020, 148 (1).

169. Chen, M. L.; Yin, B. S.; Song, J. X., Recent Development of Constructing Porphyrin Arrays via Suzuki-Miyaura Cross-Coupling Reaction. Progress in Chemistry 2015, 27 (6), 641-654.

170. Li, W. T.; Zhang, H.; Shi, S. W.; Xu, J. X.; Qin, X.; He, Q. Q.; Yang, K. C.; Dai, W. B.; Liu, G.; Zhou, Q. G.; Yu, H. Z.; Silva, S. R. P.; Fahlman, M., Recent progress in silver nanowire networks for flexible organic electronics. Journal of Materials Chemistry C 2020, 8 (14), 4636-4674.

171. Fang, Y. Y.; Jiang, X. Q.; Ou, Z. P.; Michelin, C.; Desbois, N.; Gros, C. P.; Kadish, K. M., Redox properties of nitrophenylporphyrins and electrosynthesis of nitrophenyl-linked $\mathrm{Zn}$ porphyrin dimers or arrays. Journal of Porphyrins and Phthalocyanines 2014, 18 (8-9), 832-841.

172. Han, L.; Huang, Y. K.; Tang, W.; Chen, S. J.; Zhao, J. Q.; Guo, X. J., Reducing contact resistance in bottom contact organic field effect transistors for integrated electronics. Journal of Physics D-Applied Physics 2020, 53 (1).

173. Muresan, A. Z.; Thamyongkit, P.; Diers, J. R.; Holten, D.; Lindsey, J. S.; Bocian, D. F., Regiospecifically alpha-C-13-labeled porphyrins for studies of ground-state hole transfer in multiporphyrin arrays. Journal of Organic Chemistry 2008, 73 (18), 6947-6959.

174. Vijayaraghavan, S.; Auwarter, W.; Ecija, D.; Seufert, K.; Rusponi, S.; Houwaart, T.; Sautet, P.; Bocquet, M. L.; Thakur, P.; Stepanow, S.; Schlickum, U.; Etzkorn, M.; Brune, H.; Barth, J. V., Restoring the Co Magnetic Moments at Interfacial Co-Porphyrin Arrays by Site-Selective Uptake of Iron. Acs Nano 2015, 9 (4), 3605-3616.

175. Kwon, J. H.; Jeon, Y.; Choi, K. C., Robust Transparent and Conductive Gas Diffusion Multibarrier Based on Mg- and Al-Doped $\mathrm{ZnO}$ as Indium Tin Oxide-Free Electrodes for Organic Electronics. Acs Applied Materials \& Interfaces 2018, 10 (38), 32387-32396.

176. Spiess, H., Role of conformation of side groups in supramolecular organization of materials for organic electronics. Abstracts of Papers of the American Chemical Society 2019, 258.

177. Yang, J.; Lee, J. E.; Lee, C. Y.; Aratani, N.; Osuka, A.; Hupp, J. T.; Kim, D., The Role of Electronic Coupling in Linear Porphyrin Arrays Probed by Single-Molecule Fluorescence Spectroscopy. Chemistry-a European Journal 2011, 17 (33), 9219-9225.

178. Kim, D., The Role of Electronic Coupling in Various Porphyrin Arrays Probed by Raman and Single Molecule Fluorescence Spectroscopy. Xxii International Conference on Raman Spectroscopy 2010, 1267, 687688 .

179. Yu, J. X.; Mathew, S.; Flavel, B. S.; Johnston, M. R.; Shapter, J. G., Ruthenium porphyrin functionalized single-walled carbon nanotube arrays - A step toward light harvesting antenna and multibit information storage. Journal of the American Chemical Society 2008, 130 (27), 8788-8796.

180. Sizov, A. S.; Agina, E. V.; Ponomarenko, S. A., Self-assembled interface monolayers for organic and hybrid electronics. Russian Chemical Reviews 2019, 88 (12), 1220-1247.

181. Shen, Y. T.; Deng, K.; Li, M.; Zhang, X. M.; Zhou, G.; Muellen, K.; Zeng, Q. D.; Wang, C., Selfassembling in fabrication of ordered porphyrins and phthalocyanines hybrid nano-arrays on HOPG.

Crystengcomm 2013, 15 (27), 5526-5531.

182. Morisue, M.; Hoshino, Y.; Shimizu, K.; Shimizu, M.; Kuroda, Y., Self-complementary doublestranded porphyrin arrays assembled from an alternating pyridyl-porphyrin sequence. Chemical Science 2015, $6(11), 6199-6206$.

183. Rauch, V.; Conradt, J.; Takahashi, M.; Kanesato, M.; Wytko, J. A.; Kikkawa, Y.; Kalt, H.; Weiss, J., Self-organized porphyrin arrays on surfaces: the case of hydrophilic side chains and polar surfaces. Journal of Porphyrins and Phthalocyanines 2014, 18 (1-2), 67-75.

184. Park, S.; Heo, S. W.; Lee, W.; Inoue, D.; Jiang, Z.; Yu, K.; Jinno, H.; Hashizume, D.; Sekino, M.; Yokota, T.; Fukuda, K.; Tajima, K.; Someya, T., Self-powered ultra-flexible electronics via nanograting-patterned organic photovoltaics. Nature 2018, 561 (7724), 516-+.

185. Kang, W. M.; Ma, X. M.; Hu, M.; Jia, Z. X.; Liu, H.; Cheng, B. W., Self-templating synthesis of a fluorescent porphyrin doped poly(methyl methacrylate) nano-array and its $\mathrm{HCl}$ gas sensing properties.

Analytical Methods 2016, 8 (35), 6489-6493.

186. Yang, F.; Li, C.; Wei, Y. Z.; Yan, N. F.; Wang, X. H.; Liu, F.; You, S. Y.; Wang, J. Z.; Ma, W.; Li, W. W., A Simple, Small-Bandgap Porphyrin-Based Conjugated Polymer for Application in Organic Electronics. Macromolecular Rapid Communications 2018, 39 (21).

187. Kim, D.; Osuka, A., Single-Molecule Photophysical Properties of Various Directly Linked Porphyrin Arrays. Multiporphyrin Arrays: Fundamentals and Applications 2012, 1-54. 
188. Park, M.; Yoon, M. C.; Yoon, Z. S.; Hori, T.; Peng, X. B.; Aratani, N.; Hotta, J. I.; Uji-i, H.; Sliwa, M.; Hofkens, J.; Osuka, A.; Kim, D., Single-molecule spectroscopic investigation of energy migration processes in cyclic porphyrin arrays. Journal of the American Chemical Society 2007, 129 (12), 3539-3544. 189. Pinkerton, N. M.; Gindy, M. E.; Calero-DdelC, V. L.; Wolfson, T.; Pagels, R. F.; Adler, D.; Gao, D. Y.; Li, S. K.; Wang, R. B.; Zevon, M.; Yao, N.; Pacheco, C.; Therien, M. J.; Rinaldi, C.; Sinko, P. J.; Prud'homme, R. K., Single-Step Assembly of Multimodal Imaging Nanocarriers: MRI and Long-Wavelength Fluorescence Imaging. Advanced Healthcare Materials 2015, 4 (9), 1376-1385.

190. Shetti, V. S.; Pareek, Y.; Ravikanth, M., Sn(IV) porphyrin scaffold for multiporphyrin arrays. Coordination Chemistry Reviews 2012, 256 (23-24), 2816-2842.

191. Dvivedi, A.; Pareek, Y.; Ravikanth, M., Sn-IV Porphyrin Scaffolds for Axially Bonded Multiporphyrin Arrays: Synthesis and Structure Elucidation by NMR Studies. Chemistry-a European Journal 2014, 20 (15), 4481-4490.

192. Mardis, K. L.; Sutton, H. M.; Zuo, X. B.; Lindsey, J. S.; Tiede, D. M., Solution-State Conformational Ensemble of a Hexameric Porphyrin Array Characterized Using Molecular Dynamics and Xray Scattering. Journal of Physical Chemistry A 2009, 113 (11), 2516-2523.

193. Salzillo, T.; Rivalta, A.; Castagnetti, N.; D'Agostino, S.; Masino, M.; Grepioni, F.; Venuti, E.; Brillante, A.; Girlando, A., Spectroscopic identification of quinacridone polymorphs for organic electronics. Crystengcomm 2019, 21 (24), 3702-3708.

194. Xu, H.; Cao, K. D.; Ding, H. B.; Zhong, Q. F.; Gu, H. C.; Xie, Z. Y.; Zhao, Y. J.; Gu, Z. Z., Spherical Porphyrin Sensor Array Based on Encoded Colloidal Crystal Beads for VOC Vapor Detection. Acs Applied Materials \& Interfaces 2012, 4 (12), 6751-6756.

195. Cammidge, A. N.; Nekelson, F.; Hughes, D. L.; Zhao, Z. X.; Cook, M. J., Stepwise syntheses of complex mu-oxo-linked heterochromophore arrays containing phthalocyanine, porphyrin and subphthalocyanine ligands. Journal of Porphyrins and Phthalocyanines 2010, 14 (12), 1001-1011.

196. Kang, B.; Song, E.; Lee, S. B.; Chae, B. G.; Ahn, H.; Cho, K., Stretchable Polymer Gate Dielectric with Segmented Elastomeric Network for Organic Soft Electronics. Chemistry of Materials 2018, 30 (18), 6353-6360.

197. Ferdele, S.; Jose, B.; Foster, R.; Keyes, T. E.; Rice, J. H., Strong coupling in porphyrin J-aggregate excitons and plasmons in nano-void arrays. Optical Materials 2017, 72, 680-684.

198. Yoon, M. C.; Cho, S.; Kim, P.; Hori, T.; Aratani, N.; Osuka, A.; Kim, D., Structural Dependence on Excitation Energy Migration Processes in Artificial Light Harvesting Cyclic Zinc(II) Porphyrin Arrays. Journal of Physical Chemistry B 2009, 113 (45), 15074-15082.

199. Lee, S. H.; Yang, J.; Kim, D., Structure-Dependent Electronic Interactions in Ethyne-Bridged Porphyrin Arrays Investigated by Single-Molecule Fluorescence Spectroscopy. Journal of Physical Chemistry Letters 2016, 7 (18), 3676-3682.

200. Park, S. K.; Sun, H.; Chung, H.; Patel, B. B.; Zhang, F. J.; Davies, D. W.; Woods, T. J.; Zhao, K. J.; Diao, Y., Super- and Ferroelastic Organic Semiconductors for Ultraflexible Single-Crystal Electronics. Angewandte Chemie-International Edition 2020.

201. Satake, A.; Shoji, O.; Kobuke, Y., Supramolecular array of imizazolylethynyl-zinc-porphyrin. Journal of Organometallic Chemistry 2007, 692 (1-3), 635-644.

202. Kira, A.; Umeyama, T.; Matano, Y.; Yoshida, K.; Isoda, S.; Park, J. K.; Kim, D.; Imahori, H., Supramolecular Donor-Acceptor Heterojunctions by Vectorial Stepwise Assembly of Porphyrins and Coordination-Bonded Fullerene Arrays for Photocurrent Generation. Journal of the American Chemical Society 2009, 131 (9), 3198-+.

203. Bouamaied, I.; Nguyen, T.; Ruhl, T.; Stulz, E., Supramolecular helical porphyrin arrays using DNA as a scaffold. Organic \& Biomolecular Chemistry 2008, 6 (21), 3888-3891.

204. Wang, H. W.; Chen, C. H.; Lim, T. S.; Huang, S. L.; Luh, T. Y., Supramolecular PorphyrinDABCO Array in Single- and Double-Stranded Polynorbornenes. Chemistry-an Asian Journal 2011, 6 (2), 524-533.

205. Witkowski, N., Surface and Interface Characterization in Organic Electronics. World Scientific Reference of Hybrid Materials, Vol 2: Devices from Hybrid and Organic Materials 2019, 17, 105-132.

206. Mathew, S.; Yu, J. X.; Johnston, M. R.; Quinton, J. S.; Shapter, J. G., Surface mounted porphyrinnanotube arrays: Towards energy-harvesting surfaces. 2008 International Conference on Nanoscience and Nanotechnology 2008, 206-209.

207. Wang, S. G.; Wang, Z. W.; Li, J.; Li, L. Q.; Hu, W. P., Surface-grafting polymers: from chemistry to organic electronics. Materials Chemistry Frontiers 2020, 4 (3), 692-714.

208. Kim, T.; Kim, J.; Mori, H.; Park, S.; Lim, M.; Osuka, A.; Kim, D., Symmetry-breaking charge transfer in the excited state of directly linked push-pull porphyrin arrays. Physical Chemistry Chemical Physics 2017, 19 (21), 13970-13977. 
209. Anderson, N. T.; Dinolfo, P. H.; Wang, X., Synthesis and characterization of porphyrin-DNA constructs for the self-assembly of modular energy transfer arrays. Journal of Materials Chemistry C 2018, 6 (10), 2452-2459.

210. Kanekar, D. N. N.; Chacko, S.; Kamble, R. M. M., Synthesis and investigation of the photophysical, electrochemical and theoretical properties of phenazine-amine based cyan blue-red fluorescent materials for organic electronics. New Journal of Chemistry 2020, 44 (8), 3278-3293.

211. Finnigan, E. M.; Rein, R.; Solladie, N.; Dahms, K.; Gotz, D. C. G.; Bringmann, G.; Senge, M. O., Synthesis and ligand binding properties of triptycene-linked porphyrin arrays. Tetrahedron 2011, 67 (6), $1126-$ 1134.

212. Wang, F. L.; Tang, J. G.; Liu, J. X.; Wang, Y.; Wang, R.; Niu, L.; Huang, L. J.; Huang, Z., Synthesis and photoinduced electron transfer characteristic of a bis (zinc porphyrin)-perylene bisimide array. Journal of Physical Organic Chemistry 2011, 24 (11), 1101-1109.

213. Hao, Q. S.; Zeng, Y.; Yu, T. J.; Chen, J. P.; Yang, G. Q.; Li, Y., Synthesis and Photophysical Properties of Doubly beta-to-beta Bridged Cyclic Zn-II Porphyrin Arrays. Chemistry-an Asian Journal 2013, 8 (5), 1015-1022.

214. Tan, K. X.; Lintang, H. O.; Maniam, S.; Langford, S. J.; Bakar, M. B., Synthesis and photophysical studies of fluorenone-armed porphyrin arrays. Tetrahedron 2016, 72 (35), 5402-5413.

215. Gotz, D. C. G.; Bruhn, T.; Senge, M. O.; Bringmann, G., Synthesis and Stereochemistry of Highly Unsymmetric beta,Meso-Linked Porphyrin Arrays. Journal of Organic Chemistry 2009, 74 (21), 8005-8020.

216. Sobral, A. J. F. N.; Justino, L. L. G.; Santos, A. C. C.; Silva, J. A.; Arranja, C. T.; Silva, M. R.; Beja, A. M., Synthesis and structural characterization of a new self-assembled disulfide linked meso-tetrakisporphyrin macromolecular array. Journal of Porphyrins and Phthalocyanines 2008, 12 (7), 845-848.

217. Welsh, T. A.; Payne, A. J.; Welch, G. C., Synthesis of aromatic imide tetramers relevant to organic electronics by direct (hetero)arylation. New Journal of Chemistry 2019, 43 (24), 9333-9337.

218. Ryan, A. A.; Pouyatos, F.; Stallivieri, A.; Balaban, T. S.; Senge, M. O., Synthesis of Diazepinefused Porphyrinoids and Annulated Porphyrin Arrays. Zeitschrift Fur Naturforschung Section B-a Journal of Chemical Sciences 2014, 69 (8), 889-898.

219. Cai, H.; Fujimoto, K.; Lim, J. M.; Wang, C. J.; Huang, W. M.; Rao, Y. T.; Zhang, S. M.; Shi, H.; Yin, B. S.; Chen, B.; Ma, M.; Song, J. X.; Kim, D.; Osuka, A., Synthesis of Direct beta-to-beta Linked Porphyrin Arrays with Large Electronic Interactions: Branched and Cyclic Oligomers. Angewandte ChemieInternational Edition 2014, 53 (41), 11088-11091.

220. Ikeda, T.; Aratani, N.; Osuka, A., Synthesis of Extremely pi-Extended Porphyrin Tapes from Hybrid meso-meso Linked Porphyrin Arrays: An Approach Towards the Conjugation Length. Chemistry-an Asian Journal 2009, 4 (8), 1248-1256.

221. Golf, H. R. A.; Oltmanns, A. M.; Trieu, D. H.; Reissig, H. U.; Wiehe, A., Synthesis of Functionalized BODIPYs, BODIPY-Corrole, and BODIPY-Porphyrin Arrays with 1,2,3-Triazole Linkers Using the 4-Azido(tetrafluorophenyl)-BODIPY Building Block. European Journal of Organic Chemistry 2015, (19), 4224-4237.

222. Mori, G.; Aratani, N.; Osuka, A., Synthesis of three-dimensionally arranged porphyrin arrays via intramolecular meso-meso coupling. Tetrahedron 2007, 63 (33), 7916-7925.

223. Langford, S. J.; Woodward, C. P., Synthesis, characterisation and X-ray structure of a novel porphyrin array employing Zn-O and O-H...O bonding motifs. Polyhedron 2007, 26 (2), 338-343.

224. Maeda, K.; Nitani, M.; Uno, M., Thermocompression bonding of conductive polymers for electrical connections in organic electronics. Polymer Journal 2020, 52 (4), 405-412.

225. Bouamaied, I.; Stulz, E., Thieme Chemistry Journal Awardees - Where are They Now? Stabilisation of Porphyrins in Tetranucleotide-Bisporphyrin Arrays by Duplex Formation with Peptide Nucleic Acid. Synlett 2009, (18), 2913-2918.

226. Wang, R. B.; Ko, C. H.; Brugh, A. M.; Bai, Y. S.; Forbes, M. D. E.; Therien, M. J., Topology, Distance, and Orbital Symmetry Effects on Electronic Spin-Spin Couplings in Rigid Molecular Systems: Implications for Long-Distance Spin-Spin Interactions. Journal of Physical Chemistry A 2020, 124 (37), 7411 7415.

227. Zhao, Z. X.; Cammidge, A. N.; Cook, M. J., Towards black chromophores: mu-oxo linked phthalocyanine-porphyrin dyads and phthalocyanine-subphthalocyanine dyad and triad arrays. Chemical Communications 2009, (48), 7530-7532.

228. Osuka, A., Towards meso-meso-Linked Porphyrin Arrays and meso-Aryl Expanded Porphyrins. Chemical Record 2015, 15 (1), 143-159.

229. Brennan, B. J.; Durrell, A. C.; Koepf, M.; Crabtree, R. H.; Brudvig, G. W., Towards multielectron photocatalysis: a porphyrin array for lateral hole transfer and capture on a metal oxide surface. Physical Chemistry Chemical Physics 2015, 17 (19), 12728-12734. 
230. Brown, A.; Jeffries-El, M., Towards the development of highly conjugated BDx systems for organic electronics. Abstracts of Papers of the American Chemical Society 2018, 256.

231. Zani, L.; Dessi, A.; Franchi, D.; Calamante, M.; Reginato, G.; Mordini, A., Transition metalcatalyzed cross-coupling methodologies for the engineering of small molecules with applications in organic electronics and photovoltaics. Coordination Chemistry Reviews 2019, 392, 177-236.

232. Dahms, K.; Senge, M. O., Triptycene as a rigid, 120 degrees orienting, three-pronged, covalent scaffold for porphyrin arrays. Tetrahedron Letters 2008, 49 (37), 5397-5399.

233. Schroder, S.; Strunskus, T.; Rehders, S.; Gleason, K. K.; Faupel, F., Tunable polytetrafluoroethylene electret films with extraordinary charge stability synthesized by initiated chemical vapor deposition for organic electronics applications. Scientific Reports 2019, 9.

234. Zhu, T.; Zheng, L. Y.; Yi, C.; Yu, T. Z.; Cao, Y.; Liu, L.; Gong, X., Two-Dimensional Conjugated Polymeric Nanocrystals for Organic Electronics. Acs Applied Electronic Materials 2019, 1 (8), 1458-1464. 235. Hill, J. P.; Wakayama, Y.; Akada, M.; Ariga, K., Two-dimensional molecular array of porphyrin derivatives with bright and dark spots as a model of two-digit molecular-dot memory. Synthetic Metals 2009, 159 (9-10), 765-768.

236. Cebrian, C., Ullazine-based materials: towards novel opportunities in organic electronics. Journal of Materials Chemistry C 2018, 6 (44), 11943-11950.

237. Seong, K. D.; Kim, J. M.; Kang, J.; Hwang, M.; Lee, C.; Piao, Y., An Ultradurable and Uniform $\mathrm{Cu}$ Electrode by Blending Carbon Nanotube Fillers in Copper-Based Metal-Organic Decomposition Ink for Flexible Printed Electronics. Advanced Materials Interfaces 2018, 5 (16).

238. Rhee, H.; Joo, T.; Aratani, N.; Osuka, A., Ultrafast energy transfer in the soret band of linear porphyrin arrays. Ultrafast Phenomena Xv 2007, 88, 480-+.

239. Ventura, B.; Flamigni, L.; Beyler, M.; Heitz, V.; Sauvage, J. P., Unusual Photoinduced Electron Transfer from a Zinc Porphyrin to a Tetrapyridyl Free-Base Porphyrin in a Noncovalent Multiporphyrin Array. Chemistry-a European Journal 2010, 16 (29), 8748-8756.

240. Leonardi, M. J.; Palomaki, P. K. B.; Dinolfo, P. H., Using copper(I)-catalyzed azide-alkyne cycloaddition in the creation of triazole linked multi-porphyrin arrays. Abstracts of Papers of the American Chemical Society 2010, 240.

241. Bruce, R. C.; Wang, R. B.; Rawson, J.; Therien, M. J.; You, W., Valence Band Dependent Charge Transport in Bulk Molecular Electronic Devices Incorporating Highly Conjugated Multi-[(Porphinato)Metal] Oligomers. Journal of the American Chemical Society 2016, 138 (7), 2078-2081.

242. Korolkov, V. V.; Svatek, S. A.; Summerfield, A.; Kerfoott, J.; Yang, L. X.; Taniguchi, T.; Watanabe, K.; Champness, N. R.; Besley, N. A.; Beton, P. H., van der Waals-Induced Chromatic Shifts in Hydrogen-Bonded Two-Dimensional Porphyrin Arrays on Boron Nitride. Acs Nano 2015, 9 (10), $10347-$ 10355.

243. Kim, K. S.; Lim, J. M.; Osuka, A.; Kim, D., Various strategies for highly-efficient two-photon absorption in porphyrin arrays. Journal of Photochemistry and Photobiology C-Photochemistry Reviews 2008, 9 (1), 13-28.

244. Seo, D. G.; Lee, Y.; Go, G. T.; Pei, M.; Jung, S.; Jeong, Y. H.; Lee, W.; Park, H. L.; Kim, S. W.; Yang, H.; Yang, C.; Lee, T. W., Versatile neuromorphic electronics by modulating synaptic decay of single organic synaptic transistor: From artificial neural networks to neuro-prosthetics. Nano Energy 2019, 65.

245. Zhao, P.; Zhu, L. L., Virtual special issue: Organic and polymer materials for electronics. Chinese Chemical Letters 2018, 29 (12), 1706-1708.

246. Long, J.; Xu, J. H.; Xia, S., Volatile Organic Compound Colorimetric Array Based on Zinc Porphyrin and Metalloporphyrin Derivatives. Proceedings of International Conference on Smart Grid and Clean Energy Technologies (Icsgce 2011) 2011, 12.

247. Uttiya, S.; Pratontep, S.; Bhanthumnavin, W.; Buntem, R.; Kerdcharoen, T., Volatile Organic Compound Sensor Arrays Based on Zinc Phthalocyanine and Zinc Porphyrin Thin Films. 2008 2nd Ieee International Nanoelectronics Conference, Vols 1-3 2008, 618-+.

248. Lim, Y. J.; Lee, J. H., Ytterbium Test for Water Vapor Transmission Rate Measurement of Passivation Film for Organic Electronics. Applied Chemistry for Engineering 2018, 29 (4), 484-487. 249. Syafaat, F.; Gunlazuardi, J., Zinc-porphyrin-imide type sensitized TiO2 nanotube arrays as photoactive electrode in a dyes sensitized solar cell. International Symposium on Current Progress in Functional Materials 2017, 188.

250. Yoon, Z. S.; Easwaramoorthi, S.; Kim, D., Zn(II)porphyrin helical arrays: A strategy to overcome conformational heterogeneity by host-guest chemistry. Bulletin of the Korean Chemical Society 2008, 29 (1), 197-201. 